\title{
Tidal Modulation of Antarctic Ice Shelf Melting
}

Ole Richter ${ }^{1,2}$, David E. Gwyther ${ }^{1}$, Matt A. King ${ }^{2}$, and Benjamin K. Galton-Fenzi ${ }^{3}$

${ }^{1}$ Institute for Marine and Antarctic Studies, University of Tasmania, Private Bag 129, Hobart, TAS, 7001, Australia.

${ }^{2}$ Geography \& Spatial Sciences, School of Technology, Environments and Design, University of Tasmania, Hobart, TAS, 7001, Australia.

${ }^{3}$ Australian Antarctic Division, Kingston, TAS, 7050, Australia.

Correspondence: Ole Richter (ole.richter@utas.edu.au)

This is a non-peer reviewed preprint submitted to EarthArXiv. This preprint has also been submitted to The Cryosphere for peer review. 
Abstract. Tides influence basal melting of individual Antarctic ice shelves, but their net impact on Antarctic-wide ice-ocean interaction has yet to be constrained. Here we quantify the impact of tides on ice shelf melting and the continental shelf seas by means of a $4 \mathrm{~km}$ resolution circum-Antarctic ocean model. Activating tides in the model increases the total basal mass loss by $57 \mathrm{Gt} / \mathrm{yr}(4 \%)$, while decreasing continental shelf temperatures by $0.04{ }^{\circ} \mathrm{C}$, indicating a slightly more efficient conversion of ocean heat into ice shelf melting. Regional variations can be larger, with melt rate modulations exceeding $500 \%$ and temperatures changing by more than $0.5{ }^{\circ} \mathrm{C}$, highlighting the importance of capturing tides for robust modelling of glacier systems and coastal oceans. Tide-induced changes around the Antarctic Peninsula have a dipolar distribution with decreased ocean temperatures and reduced melting towards the Bellingshausen Sea and warming along the continental shelf break on the Weddell Sea side. This warming extends under the Ronne Ice Shelf, which also features one of the highest increases in area-averaged basal melting (150\%) when tides are included. Further, by means of a singular spectrum analysis, we explore the processes that cause variations in melting and its drivers in the boundary layer over periods of up to one month. At most places friction velocity varies at tidal timescales (one day or faster), while thermal driving changes at slower rates (longer than one day). In some key regions under the large cold-water ice shelves, however, thermal driving varies faster than friction velocity and this can not be explained by tidal modulations in boundary layer exchange rates alone. Our results suggest that large scale ocean models aiming to predict accurate ice shelf melt rates will need to explicitly resolve tides.

\section{Introduction}

Changes in the ocean have been identified to drive melting at the base of Antarctic ice shelves with consequences for sea-level rise and global climate (e.g. Pritchard et al., 2012; Liu et al., 2015; Bronselaer et al., 2018). The oceanic mechanisms that govern the heat transport across the continental shelf and within sub-ice shelf cavities, however, remain poorly understood and quantified, causing large uncertainties in the prediction of future changes (e.g. Asay-Davis et al., 2017; Turner et al., 2017).

One relevant mechanism is ocean tides, as they interact with ice shelves in many ways including ice shelf basal melting (Padman et al., 2018). At the ice base, tidal currents enhance the turbulent exchange of heat and salt through the ice-ocean boundary layer and, hence, modulate local melt rates as well as melt water driven buoyant plumes that affect ice-ocean interaction downstream (MacAyeal, 1984; Makinson and Nicholls, 1999). Away from the ice shelf base, friction at the sea bed and underneath static sea ice contributes to ocean mixing (e.g. Padman et al., 2009; Llanillo et al., 2019), as does breaking of internal waves excited by tidal oscillating flow over steep sloping topography (e.g. Padman et al., 2006; Foldvik et al., 1990). Further, tidal currents can be rectified into a mean flow component (Loder, 1980) with velocity magnitudes comparable to the ambient circulation (Padman et al., 2009; MacAyeal, 1985). By means of these mechanisms, tides are thought to play a fundamental role in the heat transport across the continental shelf break (Padman et al., 2009; Stewart et al., 2018), vertical mixing and advection at the ice front (Gammelsrod and Slotsvik, 1981; Foldvik et al., 1985; Makinson and Nicholls, 1999) and upwelling of warm deep water inside sub-ice shelf cavities (MacAyeal, 1984). The roles of these processes for ice shelf-ocean interaction in an Antarctic-wide context, however, are not well understood, restraining reliable parameterisations in large scale climate simulations (Asay-Davis et al., 2017; Jourdain et al., 2019). 
Regional ocean-ice shelf models that explicitly resolve tides have now been successfully applied to all large ice shelves around Antarctica (e.g. Makinson et al., 2011; Mueller et al., 2012, 2018; Galton-Fenzi et al., 2012; Robertson, 2013; Arzeno et al., 2014; Mack et al., 2017; Jourdain et al., 2019). The combined domains, however, do not cover all of the Antarctic coastline, neglecting the potentially important contribution of small ice shelves (discussed in, e.g. Timmermann et al., 2012) and ice shelf teleconnections (Gwyther et al., 2014; Silvano et al., 2018). Also, inconsistent design and parameter choices make it difficult to identify the governing processes on a continent-wide scale. In contrast, Ocean General Circulation Models (OGCMs) that have global coverage and include tidal currents have not been augmented by an ice shelf component (Savage et al., 2017; Stewart et al., 2018). To our best knowledge, no Antarctic-wide ocean model that resolves ice shelf interactions and tides simultaneously has so-far been developed (Asay-Davis et al., 2017).

Here, using an Antarctic-wide ocean-ice shelf model that explicitly resolves tides, we quantify the impact of tidal currents on ice shelf basal melting and the continental shelf ocean. Further, we analyse the temporal variability of the melt drivers at the ice base over periods of up to one month to explore the mechanisms that govern tidal melting.

The following section (Sect. 2) describes the model, experiments and analysis techniques used in this study. Section 3 presents the results. First, we show tide-induced annual mean changes in ice shelf melting and the continental shelf ocean. Second, we present spectral characteristics of the melt drivers at the ice base in the presence of tides. The frequency spectrum ranges from hourly to fortnightly. The result section is followed by a discussion of the implications for larger scale modelling efforts including ice sheets and global oceans (Sect. 4). The last section (Sect. 5) summarises and concludes this study.

\section{Methods}

\subsection{Model Description}

55 We derive estimates of ice shelf-ocean interaction using the Whole Antarctic Ocean Model (WAOM) at 4 km horizontal resolution (Richter et al., 2020). The reference simulation performed for this study is similar to the experiment described and evaluated by Richter et al. (2020), except for the difference in horizontal resolution (Richter et al. (2020) evaluates the $2 \mathrm{~km}$ version of the model). At $4 \mathrm{~km}$ horizontal resolution, we resolve the tidal processes critical for the focus of this study (as discussed in Richter et al. (2020)). In the following we reiterate the key points of WAOM and describe the experiments performed here. The model is based on the Regional Ocean Modeling System (ROMS) version 3.6 (Shchepetkin and McWilliams, 2005), which uses terrain-following vertical coordinates, and has been augmented by an ice shelf component (Galton-Fenzi et al., 2012). Thermodynamic ice-ocean interaction is described using the three equation melt parameterisation (Hellmer and Olbers, 1989; Holland and Jenkins, 1999) including velocity dependent exchange coefficients (McPhee, 1987) and a modification that accounts for molecular diffusion alone (Gwyther et al., 2016).

The domain covers the entire Antarctic continental shelf including all ice shelf cavities (as shown in Fig. 1). The bathymetry and ice draft topography has been taken from the Bedmap2 dataset (Fretwell et al., 2013), while boundaries for 139 individual ice shelves are based on the MEaSURES Antarctic boundaries dataset (Mouginot et al., 2016). A well known caveat of terrain following coordinates are pressure gradient errors in regions of steep sloping topography, ultimately driving spurious 
circulation patterns (Mellor et al., 1994, 1998). To minimise pressure gradient errors in WAOM, we smooth the ice draft and bottom topography using the Mellor-Ezer-Oey algorithm until a maximum Haney factor of 0.3 is reached. Further, we artificially deepen the seafloor to a minimum water column thickness of $20 \mathrm{~m}$ to ensure numerical stability (see Schnaase and Timmermann, 2019, for implications). The ocean is discretised using a uniform horizontal grid spacing of $4 \mathrm{~km}$ and 31 vertical levels with enhanced resolution towards the surface and seafloor. Running the model for one year with 2304 CPUs on $2 \times 8$ core Intel Xeon E5-2670 (Sandy Bridge) Nodes costs about 7000 CPU-hours.

\section{$\begin{array}{lll}75 & 2.2 & \text { Simulations }\end{array}$}

For this study we perform two model simulations with ocean-atmosphere-sea ice conditions from the year 2007, one with tidal forcing and one without tides. In the tidal run, we force the 13 major constituents (M2, S2, N2, K2, K1, O1, P1, Q1, MF, MM, M4, MS4, MN4) derived from the global tidal solution TPXO7.2 (Egbert and Erofeeva, 2002) as sea surface height and barotropic currents along the northern boundary of the domain (north of $60^{\circ} \mathrm{S}$ ). In this way we achieve an accuracy in the tidal height signal around the coast of Antarctica that is comparable to available barotropic tide models (assessed in King and Padman, 2005). At $10 \mathrm{~km}$ horizontal resolution WAOM has a combined root-mean-square error in tidal height complex amplitude of $27 \mathrm{~cm}$, compared to the continent-wide Antarctic Tide Gauge record (Padman et al., 2020). Evaluating tides at higher resolution would have taken considerably more resources and we expect the improvement of accuracy with finer grid spacing to be incremental. For more information about the tidal accuracy of WAOM, including the spatial distribution, see Richter et al. (2020).

Open boundary conditions and surface fluxes are identical in both simulations. The ocean outside the model domain is described using the ECCO2 reanalysis (Menemenlis et al., 2008) and includes sea surface height, barotropic and baroclinic velocities, temperature and salinity. At the surface, we prescribe daily heat and salt fluxes, which have been derived using satellite sea ice data and heat flux calculations (Tamura et al., 2011), and daily wind stress is calculated from ERA-Interim 10-m winds and bulk flux formula (Dee et al., 2011). To constrain model drift, sea surface temperature and salinity are relaxed, on an annual timescale, to estimates from the Southern Ocean State Estimate reanalysis (Mazloff et al., 2010). Furthermore, we ensure that positive salt flux from sea ice formation occurs only when sea surface temperatures are at or below freezing. We do not account for the effect of sea ice on wind stress or include an explicit model of frazil ice (as in, e.g. Galton-Fenzi et al., 2012).

Initial temperatures and salinities are also derived from $\mathrm{ECCO}$, whereby we extrapolate values under the ice shelves from ice front conditions. The tidal and non-tidal case have been run separately for 5 years using a $10 \mathrm{~km}$ version of the model followed by 2 years at $4 \mathrm{~km}$ resolution. By performing parts of the spin up at lower resolution, we save computational costs, while still ensuring a quasi-equilibrium of the continental shelf ocean. Annual average results have been derived from the final year of the $4 \mathrm{~km}$ simulations, while mean tidal current speed and time series analysis is based on additional subsequent integration for 30 days of the tidal case. 


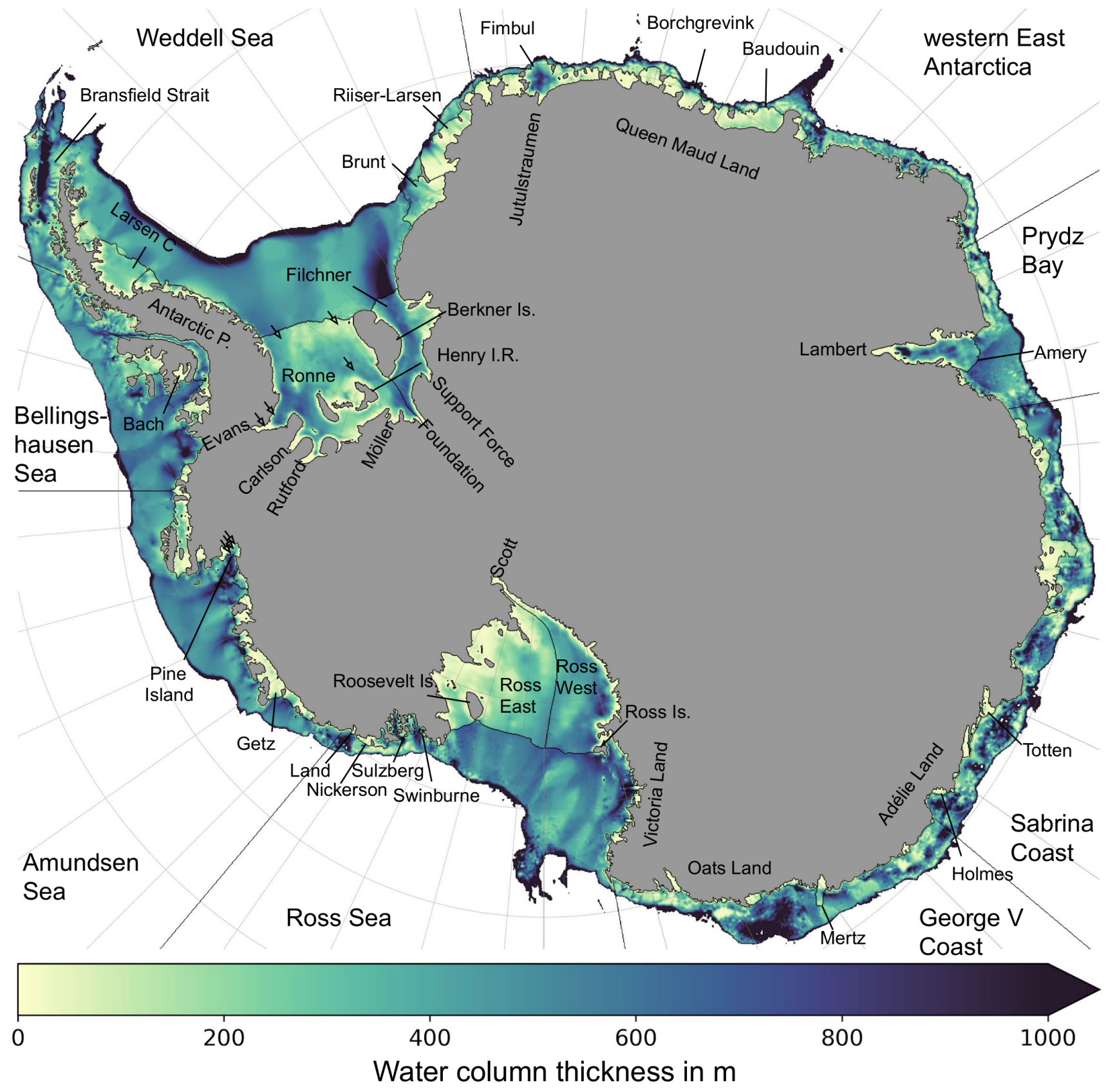

Figure 1. Study area and water column thickness on the continental shelf. Colours show the seafloor depth on the open continental shelf and water column thickness where ice shelves are present. The labels indicate locations referred to in the text with ice sheet regions and tributary glaciers on land, and ice shelves and ocean sectors on water. Arrows under Ronne and Pine Island Ice Shelf indicate the locations of the time series shown in Fig. 6. Abbreviations are Island (Is.), Ice Rise (I.R.) and Peninsula (P.). 


\subsection{Analysis}

The spatial characteristics of the mean tidal current speed are calculated as:

$$
|u|_{\text {tide }}=\left\langle\sqrt{u_{b}^{2}+v_{b}^{2}}\right\rangle_{t} \quad\left[\mathrm{~m} \mathrm{~s}^{-1}\right],
$$

whereby $u_{b}$ and $v_{b}$ are the orthogonal components of hourly averaged barotropic currents of the 30 day simulation with tides and \langle\rangle$_{t}$ denote temporal averaging. With 30 days we cover 2 full spring-neap cycles of the major semidiurnal and diurnal tidal constituents M2, S2, K1 and O1. Tidal currents typically reach a maximum speed of two times $|u|_{\text {tide }}$.

By means of Singular Spectrum Analysis (SSA; Elsner and Tsonis, 1996), we decompose variations in the melt drivers at the ice base to infer the role of tidal currents. SSA is a powerful time series analysis technique, that has been used before to derive insights into global climate models (Monselesan et al., 2015) and ice shelf-ocean interaction (Gwyther et al., 2018). The method is based on singular value decomposition of the time lagged covariance matrix and can be used to calculate the variance contribution from individual frequency ranges. In this study we use SSA to determine the in-band contribution of processes faster than 24 hours to the total variance of 30 day signals; we attribute this contribution to tidal currents alone, as they are the only source of sub-daily variability in the model.

We apply this technique to thermal driving ( $T^{*}$, the difference in temperature across the ice-ocean boundary layer) and friction velocity ( $u^{*}$, controlling the exchange rates of heat and salt through the boundary layer). Change in the covariation of $T^{*}$ and $u^{*}$ is a good approximation for melt rate variations when using the three equation melt parameterisation (e.g. Jourdain et al., 2019):

$$
w_{b} \propto u^{*} T^{*} \quad\left[\mathrm{~m} \mathrm{yr}^{-1}\right]
$$

Applying the SSA to $T^{*}$ and $u^{*}$, rather than melt rates directly, offers a first step towards separating the processes that drive melting (e.g. Mueller et al., 2018).

\section{Results}

\subsection{Mean Changes in Ice Shelf Melting and Coastal Oceans}

The area-integrated impact of tides on modelled annual-average melting and continental shelf ocean temperatures is small as shown in Table 1 . The total basal mass loss increases by $4 \%$ when including tides in the model, while ocean temperatures slightly drop, indicating more melt water and an overall increase in the efficiency at which heat is converted to melting.

The effects of tides on individual ice shelves, however, can be large. Figure 2 presents the spatial distribution of ice shelf melting around Antarctica as well as the sensitivity of these melt rates to tides. Tides modulate melting all around the continent (Fig. 2c), but mostly impact ice-ocean interaction underneath the large cold cavity ice shelves (Filchner-Ronne, Ross, Amery 


$\begin{array}{lrrr}\text { Average melt rate } & 0.90 \mathrm{~m} / \mathrm{yr} & 0.93 \mathrm{~m} / \mathrm{yr} & 0.04 \mathrm{~m} / \mathrm{yr} \\ \text { Basal mass loss } & 1388 \mathrm{Gt} / \mathrm{yr} & 1445 \mathrm{Gt} / \mathrm{yr} & 57 \mathrm{Gt} / \mathrm{yr} \\ \text { Continental shelf potential temperature } & -1.38{ }^{\circ} \mathrm{C} & -1.42{ }^{\circ} \mathrm{C} & -0.04{ }^{\circ} \mathrm{C}\end{array}$

Table 1. Tide induced difference in area averaged melt rate, basal mass loss and continental shelf ocean temperatures for all Antarctic ice shelves (averaging Fig. 2c and Fig. 4). Continental shelf temperatures have been calculated using a depth at the shelf break of $1000 \mathrm{~m}$ and including the sub-ice shelf cavities.

and Larsen C; Fig. 2b), where ambient melt rates are small (Fig. 2a). Modulations in melt rate (at model horizontal resolution of $4 \mathrm{~km}$ ) have a standard deviation (std) of $352 \%$ and can be larger than 100 times of the original melt rate (calculated as $\left.\left(w_{b \text { tides }}-w_{b \text { no-tides }}\right) / w_{b \text { no-tides }}\right)$ and shown in Figure $\left.2 \mathrm{c}\right)$. Areas of increased melting are often in close vicinity of areas of reduced melting or increased marine ice accretion, leading to smaller effects when considering ice shelf area averages (std = $37 \%$; see Table A1).

These small scale modulations can often be linked to local tidal current strength. Figure 3 shows the barotropic currents associated with tides. These currents include the annual mean circulation (Fig. 3a), the mean tidal current strength (calculated following Eqn. 1 and shown in Fig. 3b; see Section 2.3) and the sensitivity of the annual mean circulation to tides (Fig. 3c). The sub-ice shelf cavities can become very narrow where streams of grounded ice drain into the large cold water ice shelves, for example, near Evans, Carlson and Rutford Ice Stream under the Ronne Ice Shelf, near the Lambert Glacier under the Amery Ice Shelf and near Scott Glacier under the Ross Ice Shelf (as shown in Fig. 2). Tides accelerate in these grounding line pockets (Fig. 3b) and act to strengthen the ice pump mechanism (Lewis and Perkin, 1986) with enhanced melting at depth followed by reduced melt rates (or increased refreezing) along western outflow regions (Fig. 2c). A similar pattern is also apparent under the Fimbul Ice Shelf, where a melt increase near the grounding line of the Jutulstraumen Glacier coincides with reduced melt rates all along its keel (Fig. 2c). We note that we artificially deepened the bathymetry in narrow grounding zones and all of the regions mentioned above are affected by this approach (see Section 2.1). We also note that peaks in tidal velocity away from the grounding zones are often met by localised melt increases, for example, underneath Riiser-Larsen Ice Shelf and the ice shelves of Queen Maud Land, but also in the Amundsen-Bellingshausen Seas underneath the Getz and Bach ice shelves.

Melting in the frontal parts of ice shelves is often associated with local tidal activity. While our results indicate strong melting at the ice shelf front all around the continent (see Fig. 2a), in most regions this melting is independent from tides (as shown in Fig. 2b). Only at few places do tides contribute substantial amounts to front melting, for example, west of Berkner Island, east of Ross Island and under the Mertz Glacier tongue. Figure 4 shows the sensitivity of depth averaged continental shelf ocean temperature to tides and, in the regions mentioned, adjacent shelf temperatures do not show significant warming in the presence of tides. Hence, front melting at these locations is likely driven by tidal advection of solar heated surface waters (proposed by Jacobs et al., 1992; see, e.g. Stewart et al., 2019, for observational evidence). 

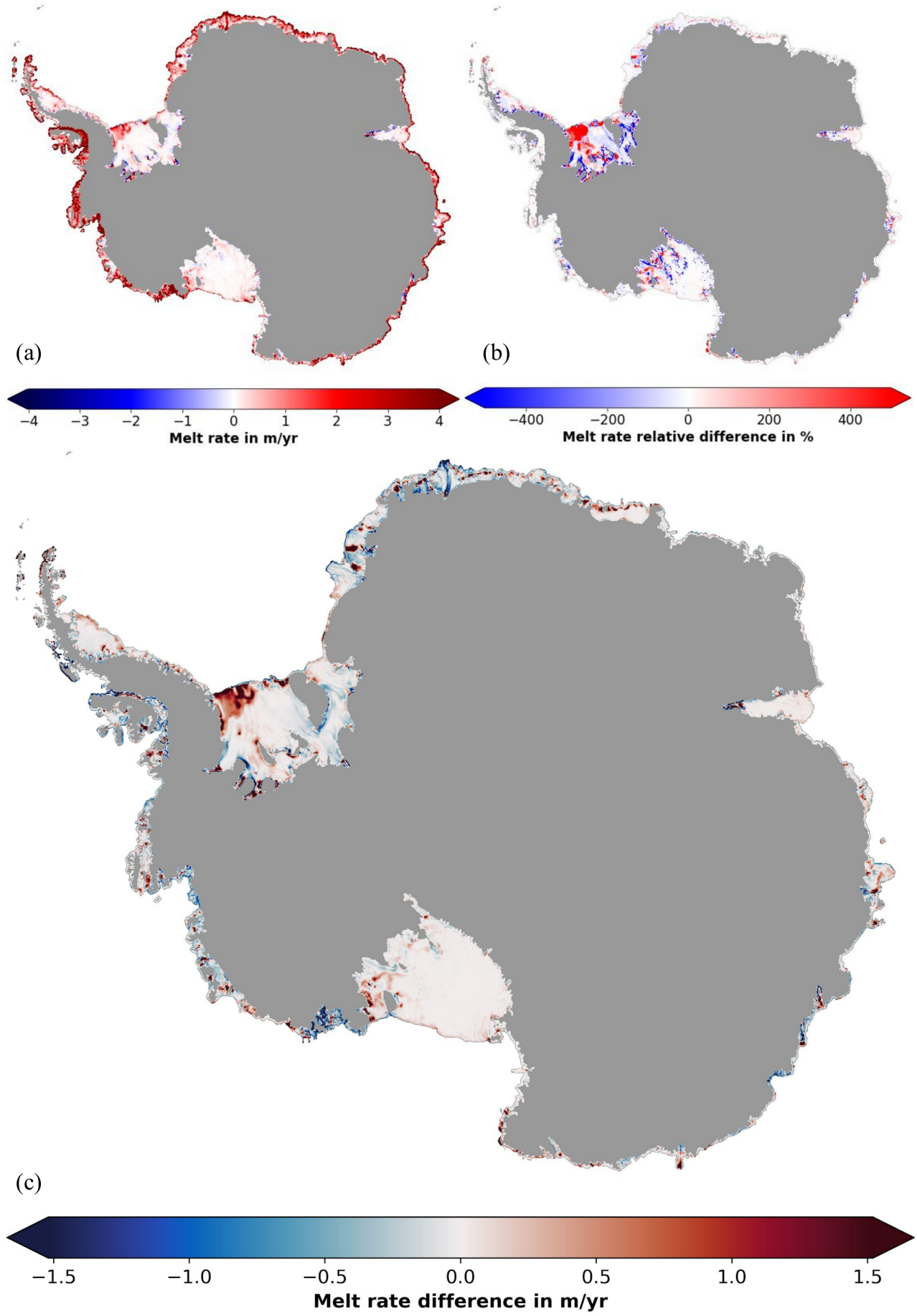

Figure 2. Tidal melting of Antarctic ice shelves. a) Annual average ice shelf melting for the case with tides, b) its relative difference to the case without tides $\left(\left(w_{b}\right.\right.$ tides $-w_{b}$ no-tides $) / w_{b}$ no-tides $)$ and $\left.c\right)$ its absolute difference to the case without tides $\left(w_{b}\right.$ tides $-w_{b}$ no-tides $)$. 

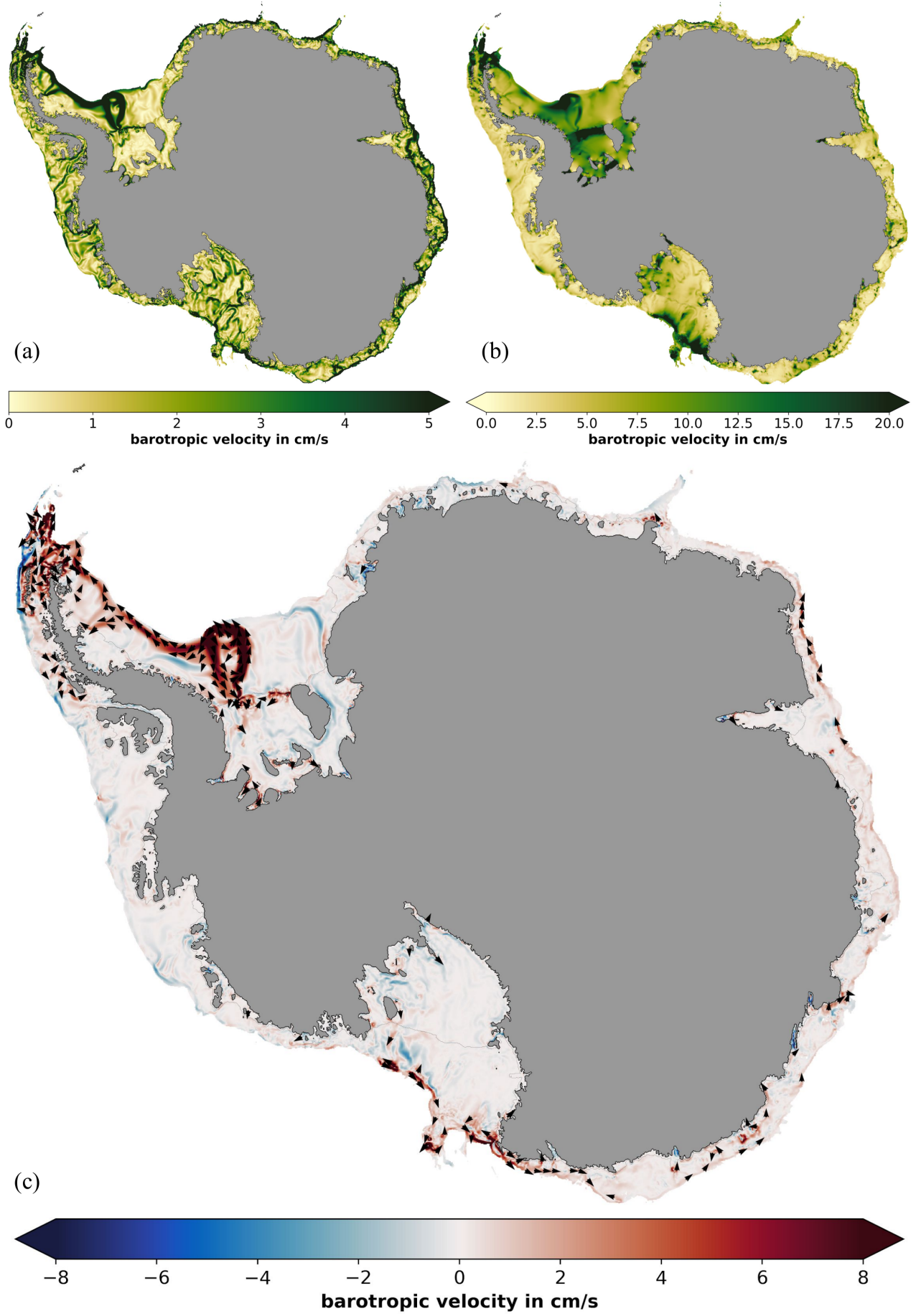

Figure 3. Tide induced currents around Antarctica. a) mean barotropic velocities from the simulation with tides, b) mean speed of oscillating tidal currents $\left(|u|_{\text {tide }}\right.$, calculated following Eqn. 1; see Section 2.3) and c) the difference of a) to the the simulation without tides $\left(|u|_{b \text { tides }}-\right.$ $|u|_{b \text { no-tides }}$ ). Arrows in (c) indicate the change in barotropic flow direction when activating tides and are only shown in places where velocity change is greater than $1 \mathrm{~cm} / \mathrm{s}$. 


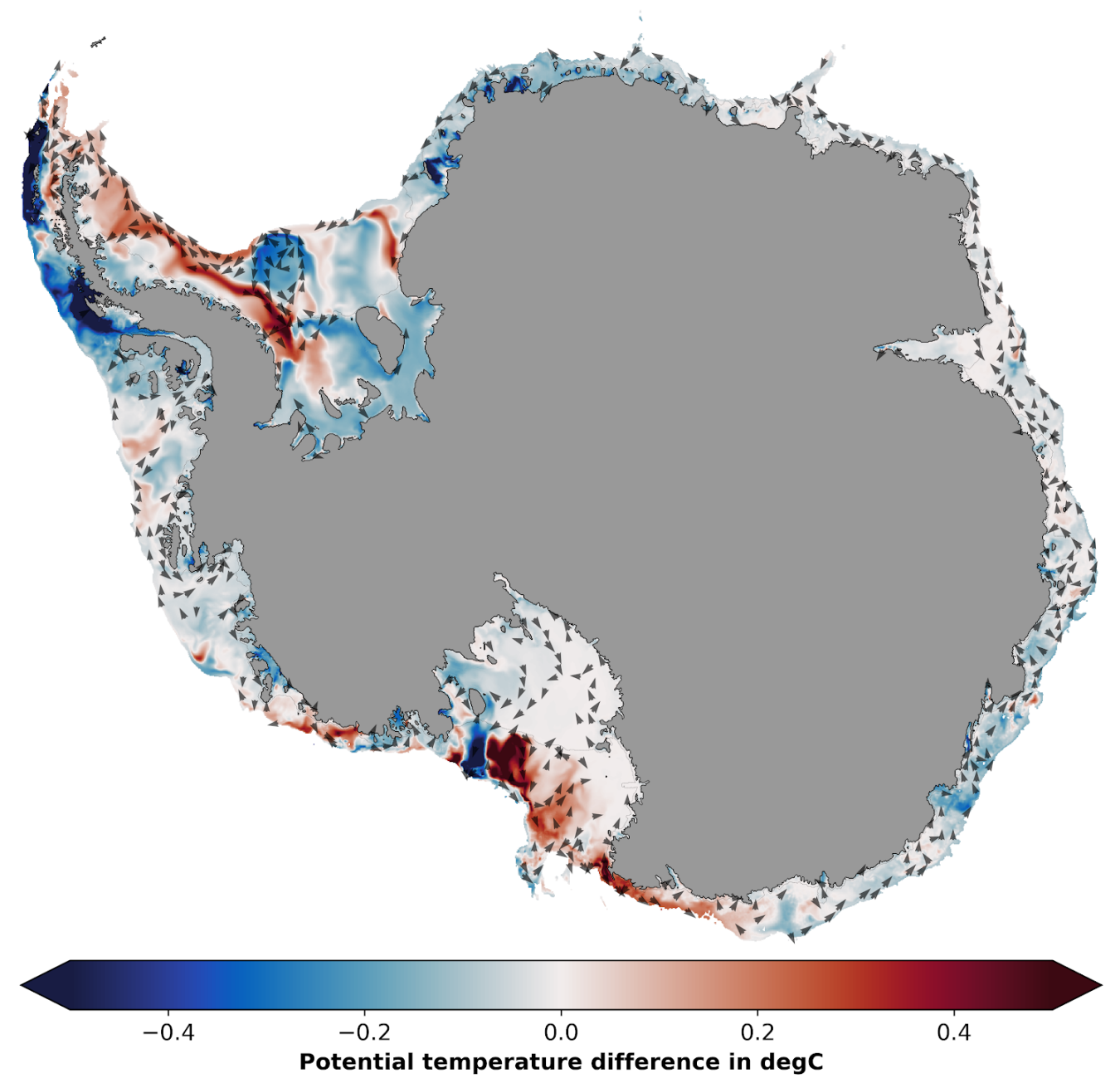

Figure 4. Changes in continental shelf ocean temperatures induced by tides. Difference in depth- average potential temperature when activating versus not activating tides in the model $\left(\Theta_{\text {tides }}-\Theta_{\text {no-tides }}\right)$. Arrows indicate barotropic flow direction of the run with tides and are shown only where velocities are stronger than $2 \mathrm{~cm} / \mathrm{s}$. 
At some locations, tides act to increase melting across larger areas and these locations always coincide with a nearby warming

155

of the continental shelf ocean (compare Fig. 2c with Fig. 4). We attribute strong melting underneath the north-western side of the Ronne Ice Shelf to tide driven circulation on the adjacent continental shelf. The M2 tide resonates with the topography of the Weddell Sea causing a large tidal wave to circulate along the coastline of this region. When activating tides in our model, a strong gyre forms with its centre close to the midpoint of the rotating tidal wave, called the amphidromic point (for location of the M2 amphidromic point in the Weddell Sea see, e.g. Rosier et al., 2014, their Fig. 1a). The gyre transports heat across the continental shelf break and causes the Ronne Ice Shelf to feature one of the largest increases in average melting (128\%, equivalent to 44 Gigatons of ice per year, see Table A1). Tide induced strengthening of warm water intrusions onto the continental shelf can also be seen in the northwestern Ross Sea, around the tip of the Antarctic Peninsula, seaward of Brunt Ice Shelf (eastern Weddell Sea) and in front of Land Ice Shelf (western Amundsen Sea).

Where melting increases in the presence of tides, consequent changes in melt water affect the ocean and ice shelf melting far downstream from its origin. Besides tide-induced changes in continental shelf temperatures, Figure 4 also indicates the direction of the mean circulation in the presence of tides. The warming of the western part of the Ronne Ice Shelf Gyre, for example, is met by cooling along its eastern side after passing through the sub-ice shelf cavity. Likewise, the predominantly increased melting around Roosevelt Island (eastern Ross Ice Shelf, Fig. 2c) coincides with a northerly mean flow and strong cooling of the adjacent continental shelf ocean. At a larger scale, the westward flowing current through Bransfield Strait (Antarctic Peninsula) seems to connect tide-induced warming and melting in the western Weddell Sea with the overall cooling and reduction in melt rates in the eastern Bellingshausen Sea. Another example of ice shelf teleconnections is apparent in the western Amundsen Sea. Here, westward currents on the continental shelf seem to transport tide-induced melt water from the Land Ice Shelf underneath the adjacent ice shelves Nickerson, Sulzberg and Swinburne, all of which featuring a reduction in melting. The westward propagation of melt water in this region has also been suggested by previous studies (Jacobs and Giulivi, 2010; Nakayama et al., 2014a). Further, high melt rates along Oates Land and the George V Coast probably contribute to the colder temperatures on the continental shelf seaward of Adélie Land and the reduced melting under Holmes Ice Shelf. Finally, cooler waters off the coast of Queen Maud Land only appear after the westward circulation passes through enhanced melting under Baudouin and Borchgrevink Ice Shelves. Tides also act to increase the Antarctic Slope Current (shown in Fig. 3c) at many places (e.g. in the Ross Sea, western Weddell Sea and in East Antarctica) and this likely supports far field effects of glacial melt water.

\subsection{Time Series Analysis of Melt Drivers at the Ice Base}

After quantifying the impact of tides on annual mean ice shelf melting and coastal oceans, we now explore variations in the melt drivers at the ice base at hourly resolution. The main result of this analysis is that tides control the sub monthly variability of $T^{*}$ and $u^{*}$ at most places around Antarctica. The underlying processes are either local with sub daily timescales, or include modulations of buoyant plumes with fortnightly timescales.

The model suggests that tidal currents often directly control $T^{*}$ where inflowing glaciers form narrow cavities near the grounding line of cold water ice shelves. Figure 5 shows maps that indicate how much of the sub-monthly variance of $T^{*}$ and 
$u^{*}$ is driven by processes with sub-daily timescales. Figure 6 presents the underlying times series at a few key locations. $T^{*}$ and $u^{*}$ are often directly controlled by tidal currents where, for example, Lambert Glacier (Amery Ice Shelf), Evans, Carlson, Rathford and Moeller Ice Streams (Ronne Ice Shelf) and Scotts Glacier (Ross Ice Shelf) become afloat (as shown in Fig. 5c and 5d). For example, under Evans Ice Stream, $T^{*}$ varies at half the frequency as $u^{*}$ and shows negative values (refreezing) with every second maximum in $u^{*}$ (Fig 6a). We explain this behaviour as being due to tidal advection of High Salinity Shelf Water into the pockets and supercooled water from consequent melting out of it. Interestingly, the transition between inflow and outflow can be so rapid that it reduces the contribution of sub-daily variability to the total variance of $u^{*}$. In such a case, the contribution maximum is apparent at the entrance of the narrow channel (see, e.g. Amery Ice Shelf in Fig. 5c).

The meltwater plumes that leave these narrow channels vary less at sub-daily timescales and drive thermal modulations with fortnightly periods. In the adjacent outflow regions of the grounding line melting described above, $T^{*}$ shows little sub-daily variation, and, in the case of the Evans Ice Stream, changes with the fortnightly cycle of spring and neap tide (Fig. 6b). We interpret this signature as meltwater plumes that rectify over daily, but not fortnightly periods.

In other regions with cold-water ice-shelf grounding zones, $T^{*}$ mostly varies on above daily timescales. Where Support Force and Foundation Ice Streams drain into Ronne Ice Shelf, for example, $T^{*}$ is dominated by processes acting on timescales longer than one day, while $u^{*}$ is clearly controlled by the strong tidal currents in these regions (compare Fig. 5c against Fig. $5 \mathrm{~d}$ ). Here, $T^{*}$ also exhibits strong fortnightly variations, suggesting the influence from melt water upstream (not shown).

Fortnightly tides also control the strength of the warm water intrusion under Ronne Ice Shelf. The temperatures and velocities at the base of the northwestern Ronne Ice Shelf also exhibit strong modulations following the spring neap tide (shown in Fig. 6c). As earlier identified, the source of the warm water intrusions in this area is a tide driven gyre on the adjacent continental shelf and we conclude that the strength of the M2 tide controls the strength of the gyre.

In several regions tidal currents impact the sub-monthly variability of $T^{*}$ more than that of $u^{*}$. At some areas of the trunk of the Filchner-Ronne, Ross and Riiser-Larsen Ice Shelves, sub-daily processes have a larger impact on $T^{*}$ variability than on $u^{*}$ variability (as shown by Fig. 7). We identify these regions as having strong tidal mixing, which lifts warm water up in the water column and in contact with the ice. Currents in these areas seem to include a strong fortnightly component (e.g. in the North-East of Ronne Ice Shelf and north of Henry Ice Rise, Fig. 6d and 6e, respectively), indicating the existence of buoyant plumes, which are possibly induced by the mixing-driven melt. The total sub-monthly variance of $T^{*}$ in these regions, however, is typically small (Fig. 5b), questioning the relevance of this process in a larger context. Sub-daily timescales also contribute more variance to $T^{*}$ than to $u^{*}$ in some of the grounding line pockets of Ronne and Ross ice shelves, but this is caused by short transition times of in and outflowing waters that act to reduce the contribution of fast processes to $u^{*}$ variance (as mentioned earlier).

Tidal currents are also important along the grounding zones of warm water ice shelves. The high melt rates in the AmundsenBellingshausen seas (see Fig. 2a) are often associated with deep warm water intrusions driven by eddies (e.g. Nakayama et al., 2014b; Dinniman et al., 2016). Even in the presence of strong buoyant plumes, typical for these regimes, the sub-monthly variability of $u^{*}$ and $T^{*}$ is often dominated by tidal currents (as shown by Fig. 5c and 5d). At the Pine Island Ice Shelf grounding line, for example, $u^{*}$ varies synchronously with $T^{*}$ (see Fig. 6f) and with equal contributions to the longer term 

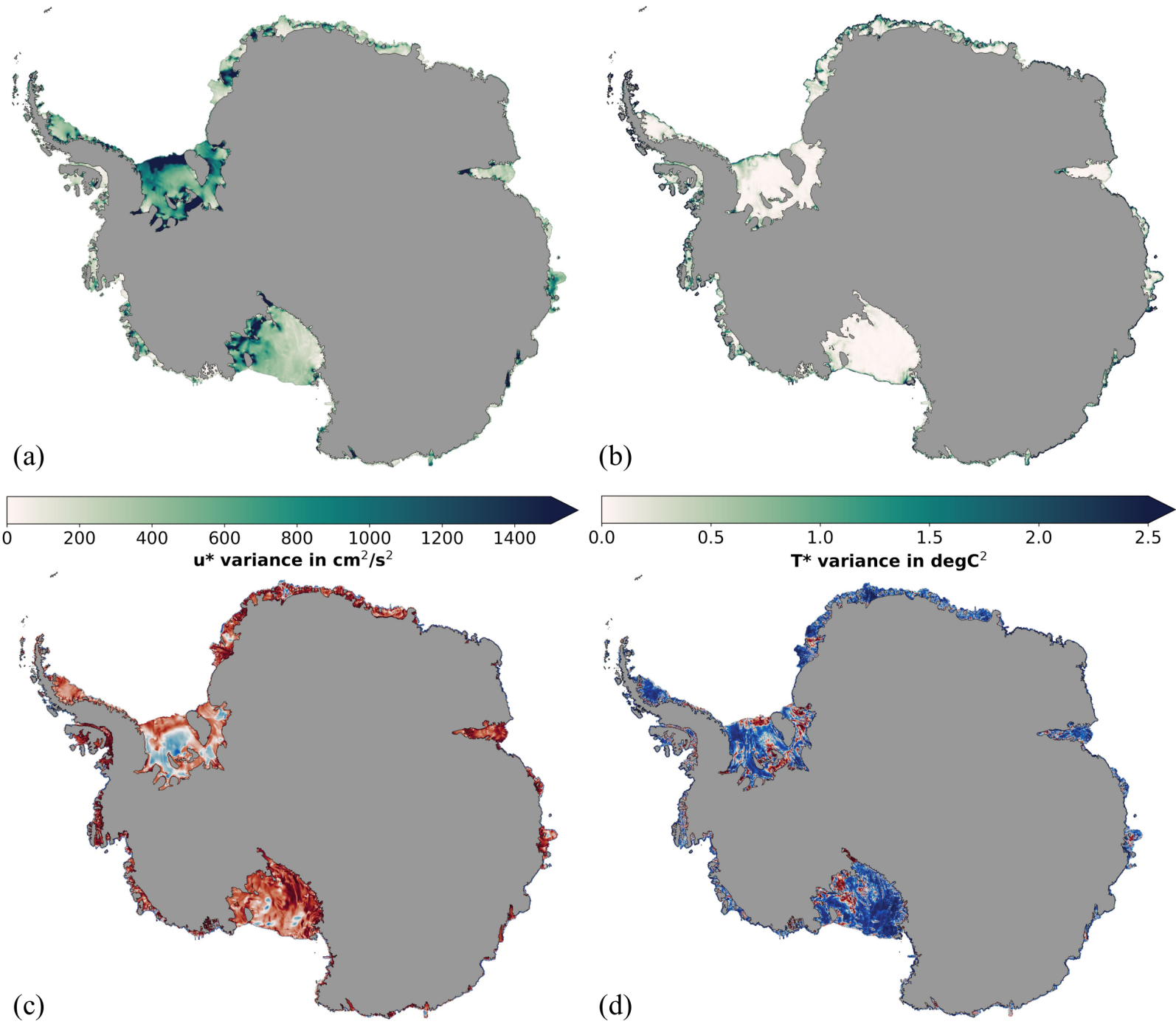

(c)

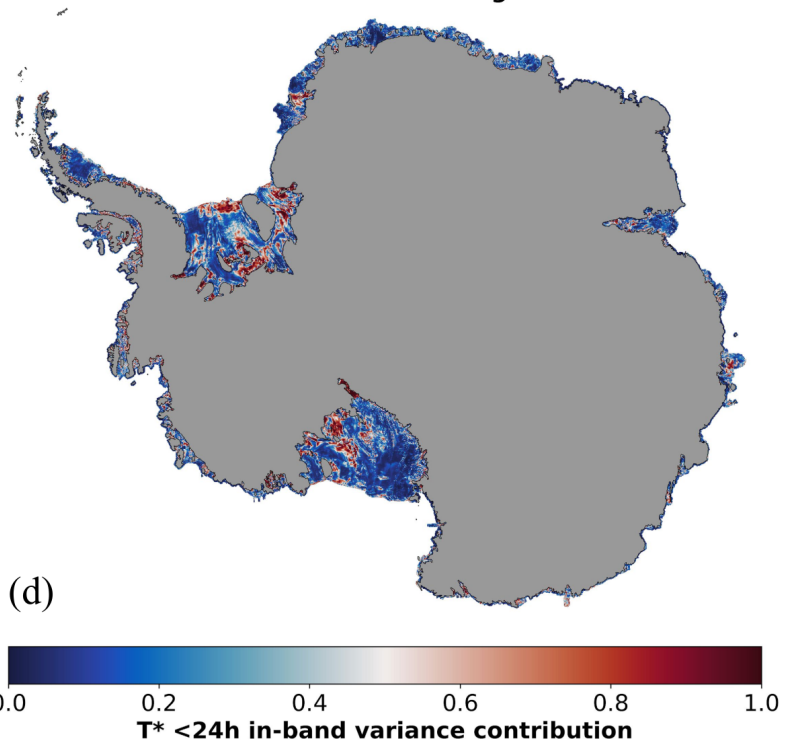

Figure 5. Contribution of tidal currents to the sub-monthly variance of the melt drivers at the ice base. (a) Sub-monthly variance of friction velocity $\left(u^{*}\right)$ and (b) thermal driving $\left(T^{*}\right)$ from the run with tides at hourly resolution. Inband contribution from processes acting on timescales faster than one day to the variance of (c) $u^{*}$ and (d) $T^{*}(0.0$ corresponds to $0 \%$ fast-process-contribution, 0.5 to equal contributions from fast and slow processes and 1.0 to $100 \%$ fast-processes-contribution). 


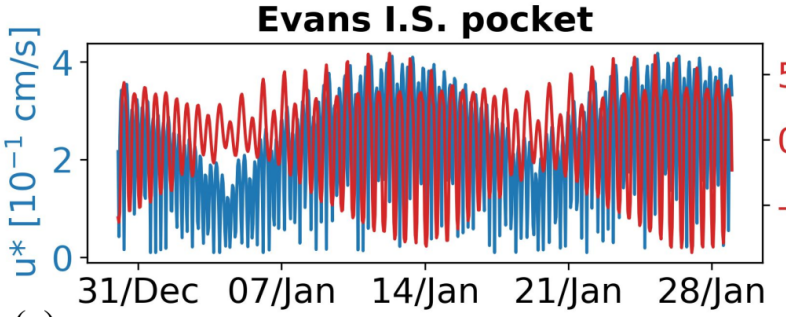

(a)

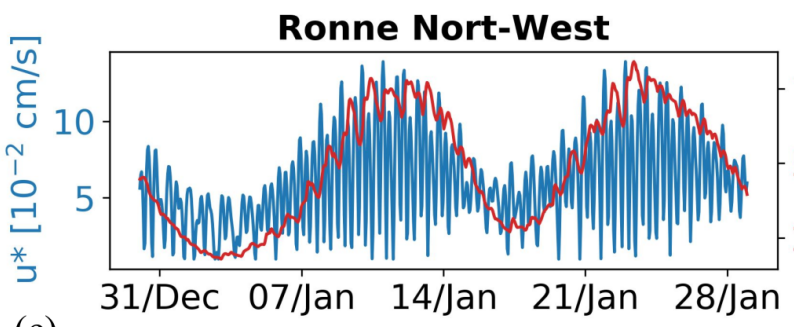

(c)

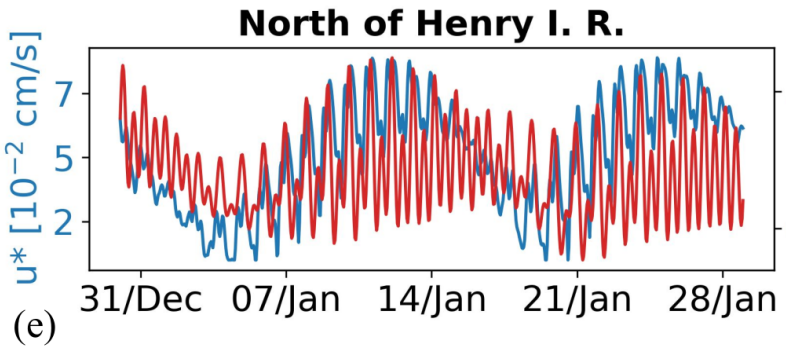
(c)

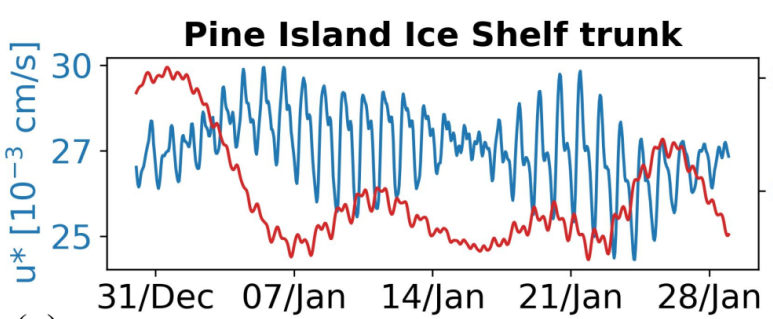
(g)

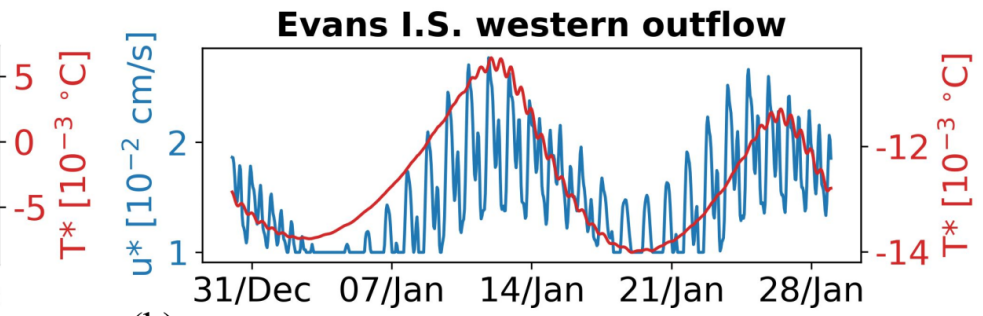

(b)

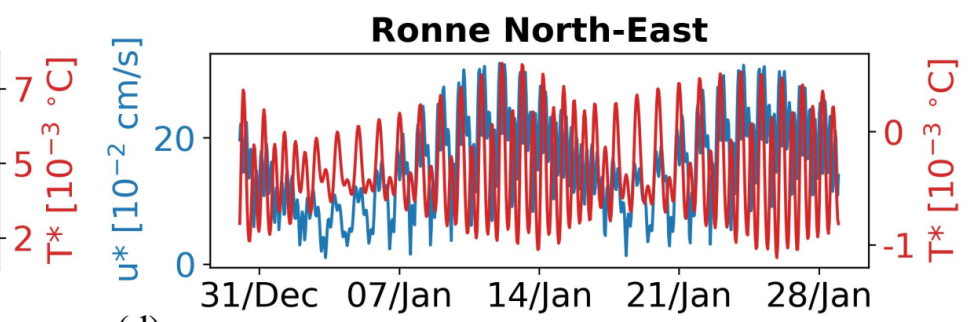

(d)
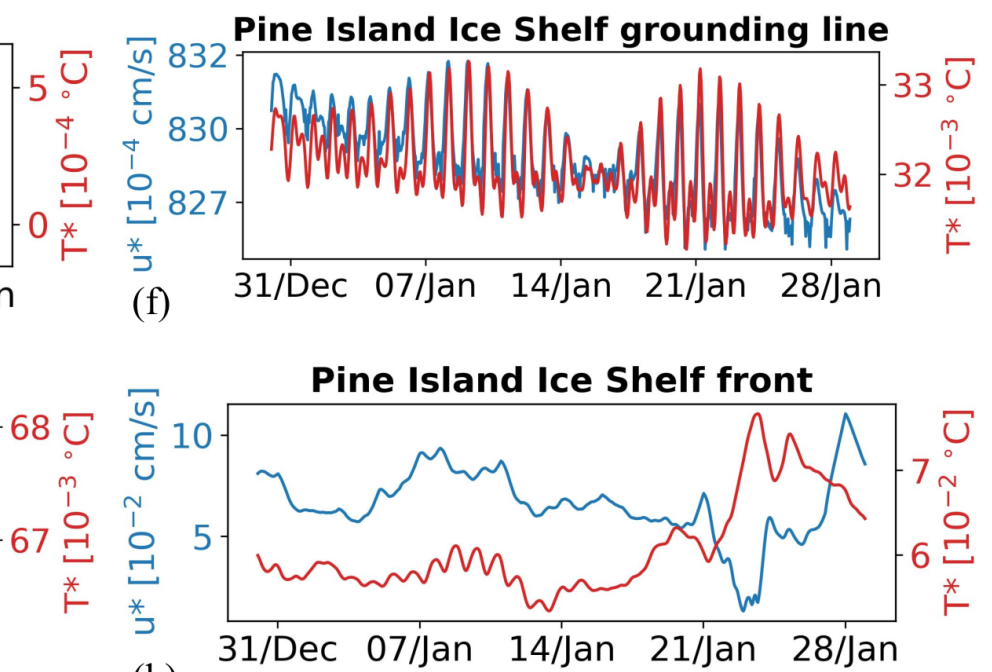

(h)

Figure 6. Selected time series of melt drivers at the ice base. Hourly average values of the friction velocity $\left(u^{*}\right.$; blue) and thermal driving $\left(T^{*}\right.$; red) during January 2007. Samples are taken from the Evans Ice Stream grounding line pocket (a), its western outflow region (b), the North-West (c) and North-East (d) of Ronne Ice Shelf, north of Henry Ice Rise (e) and, from Pine Island Ice Shelf, the grounding line (f), trunk (g) and front (h). Exact locations are indicated by arrows in Fig. 1. Note the different order of magnitude. 


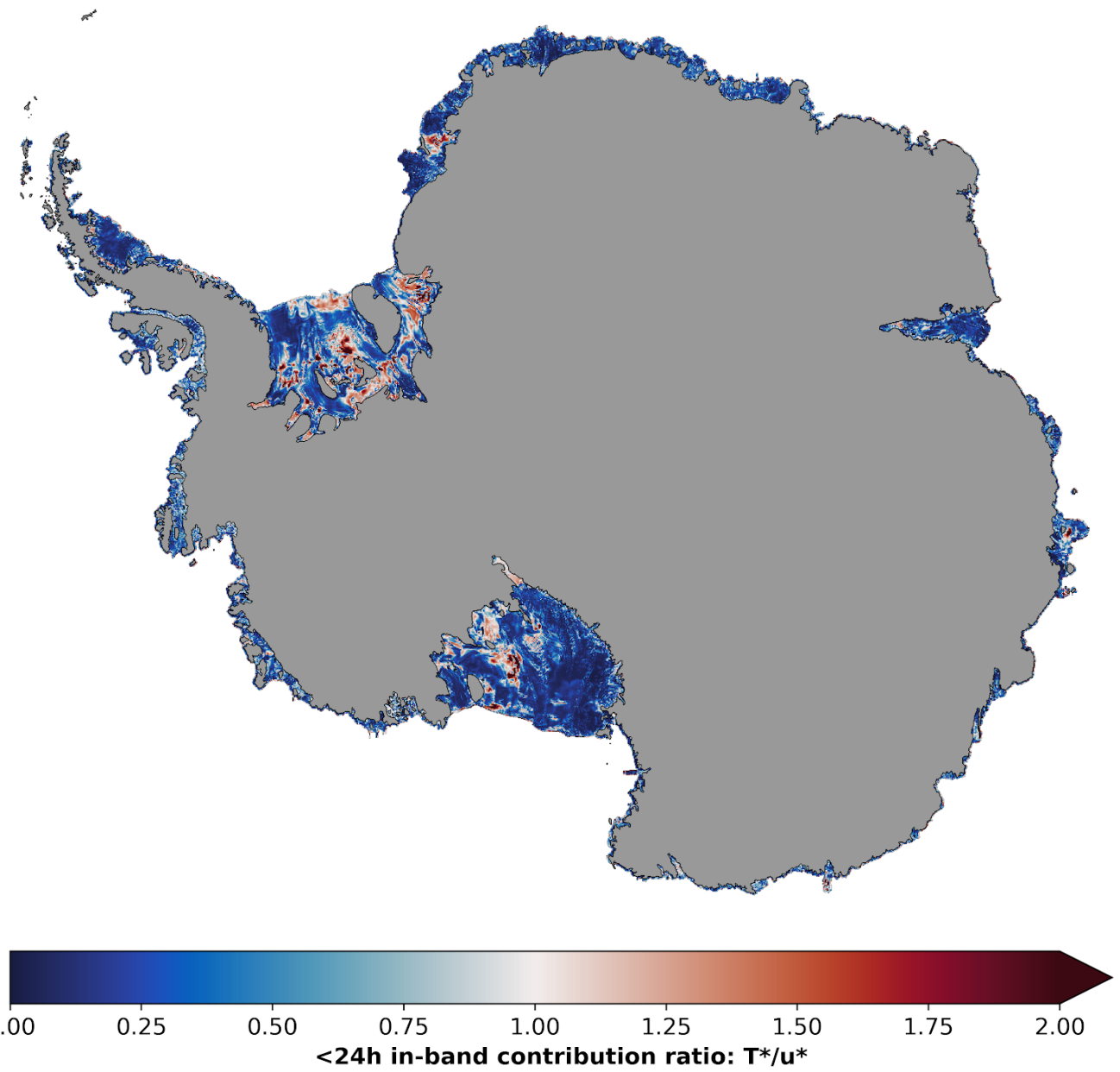

Figure 7. Ratio of tidal current variance contribution between the melt drivers at the ice base. The ratio of the $T^{*}$ fast-process variance contribution (Fig. 5d) to the $u^{*}$ fast-process variance contribution (Fig. 5c). In regions with values smaller than 1.0 fast processes impact $u^{*}$ variance more than $T^{*}$ variance, while values larger than 1.0 denote the opposite. 
variability (as shown in Fig. 7). This signature might be associated with tidal advection of warm water into the shallow, wellmixed parts of the cavity.

Other parts of warm water ice shelves, however, show little signs of tidal activity in $T^{*}$. In the Amundsen-Bellingshausen Seas, $T^{*}$ also often varies on above daily-timescales (Fig. 5c), but unlike similar regions in colder regimes, we do not find strong fortnightly cycles (as shown in Fig. 6g).

Variability in $u^{*}$ and $T^{*}$ at the ice front are often not impacted by tidal currents. The overall Antarctic picture of $T^{*}$ variability up to a month is governed by high values at the front (as shown in Fig. 5b) and at most places with dominant contributions from above-daily timescales (e.g. in the Amundsen-Bellingshausen Seas and in East Antarctica; see Fig. 5d). In these regions, $u^{*}$ is also often dominated by long period processes (Fig. 5c) and time series of $u^{*}$ and $T^{*}$ show only negligible tidal variation (e.g. at the front of the Pine Island Ice Shelf; Fig. 6h). We relate this behaviour to a strong buoyant plume, which is restricted to the very front of the ice shelves and likely controlled by the daily variation in surface fluxes or eddies. Only at very few places do tidal currents also impact frontal $T^{*}$ variability (e.g. around Ross and Roosevelt Island or at the eastern part of the Filchner Ice Shelf). Here, $u^{*}$ does not exhibit fortnightly cycles and this supports melt driven by tidal advection of warm surface waters (as mentioned earlier).

\section{Discussion}

We have shown that tidal effects on Antarctic ice shelf-ocean interaction are large and this means that robust modelling of ice shelves or the ice sheet requires inclusion of tides. That is, models including ice shelves, which are critical to the stability of the ice sheet and hence accurate ice sheet projections (Shepherd et al., 2004; Pritchard et al., 2012), need to explicitly resolve tidal currents. Tides are understood to be critically important for ocean-ice shelf interaction (e.g. Padman et al., 2018; GaltonFenzi et al., 2012), but resolving tides in larger scale models is expensive. Hence, several studies have focused on attempts to include the influence of tides on ice shelf melting without explicitly resolving tidal currents. Jourdain et al. (2019), for example, accounts for tide-driven changes in modelled melting of the Amundsen Sea ice shelves by adding a tidal component to the description of the friction velocity (following, e.g. Jenkins et al., 2010). The results of this study, however, suggest that such approaches would cause large biases in circum-Antarctic ice sheet projections.

We identified that under large parts of the cold water ice shelves tidal currents primarily interact with ice shelf melting by changing temperatures at the ice base, rather than velocities. Further, tide-induced warm water intrusions on the Weddell Sea continental shelf cause significant increases in mass loss from nearby ice shelves. Ocean changes are most pronounced near the continental shelf break and, hence, we suspect tidal mixing or rectified currents to be the driving mechanism, rather than cavity overturning from buoyant meltwater plumes.

At the ice shelf front, however, tidal currents seem to play a secondary role. Frontal melting has often been related to tidal advection of surface waters (Jacobs et al., 1992; Stewart et al., 2019) and, while the model resolves elevated melt rates of frontal ice all around the continent, tides are involved only at very few locations (e.g. east of Ross Island). Instead, surface fluxes or eddies seem to govern modulations of velocity and temperature at most places, suggesting a very localised buoyancy 
driven regime. We note, however, that the model might have biases at the outermost cells, as pressure gradient errors in sigma coordinate ocean models require smoothing of vertical boundaries (Mellor et al., 1994, 1998). To which degree a smoothed ice front is actually a better representation of frontal conditions in ocean models (as suggested by Malyarenko et al., 2019), will have to be explored in future studies.

A major limitation of this study originates from the three-equation melt parameterisation used in the model. Observations suggest that in regions with weak currents or strong stratification, the boundary layer exchange rates of heat and salt are controlled by diffusive-convection, rather than shear-driven turbulence, and the three equation melt parameterisation used in the model does not account for this regime (Kimura et al., 2014; Begeman et al., 2018). Results of this study, however, might help to inform where diffusive-convection takes place, as we expect favourable regions to exhibit weak tides and mean flow (see Fig. $3 \mathrm{~b}$ and $3 \mathrm{a}$, respectively) as well as a $T^{*}$ variability that is equally or more impacted by tidal currents than the $u^{*}$ variability (Fig. 7).

Future studies should include extended frequency analysis and experiments without thermodynamic ice-ocean interaction. A tidal harmonic analysis could shed more light on the role of the spring-neap tide for buoyant plumes, allow for the attribution of melt modulations to individual tidal constituents and help to interpret borehole observations. Performing this analysis at different months of the year should clarify how seasons impact the tide driven modulations revealed in this study. Further, additional experiments without salt and heat exchange at the ice base would help to identify the role of tide-induced meltwater plumes for exchanges across the continental shelf break and should be compared against the estimates of tide-driven shoreward heat transport of (Stewart et al., 2018).

Modelled changes in glacial melt water due to tides support the importance of ice shelf teleconnections. Regional studies suggest that meltwater can propagate far downstream (Jacobs and Giulivi, 2010; Nakayama et al., 2014a) and substantially impact ice-ocean interaction underneath other ice shelves (Gwyther et al., 2014; Silvano et al., 2018). Activating tides in our model can be seen as one large perturbation experiment and results show that tide-induced meltwater propagates far downstream at many places. A strong, tide-induced coastal current transports glacial melt water even around the tip of the Antarctic Peninsula and into the eastern Bellingshausen Seas, where it causes a significant reduction in ice-shelf melting.

280 These results stress the importance of correctly choosing boundary locations and conditions in regional studies, particularly in the presence of ice shelf teleconnections that span a wide swath of the Antarctic continental shelf.

Despite the small integrated mass loss change due to tides, the consequences for ice sheet dynamics might be large. The buttressing importance of floating ice can vary by several orders of magnitude within one ice shelf, with regions close to grounding lines, lateral boundaries or pinning points generally being the most important for ice sheet stability (Gudmundsson, 2013; Reese et al., 2018). Our model predicts that the strongest changes in basal mass loss often occur in exactly these parts of the ice shelves. Within these regions, however, increased melting is often in close vicinity to equally strong reduction in melting or enhanced refreezing, making it difficult to assess the overall impact on buttressing. Diagnostic experiments with ice sheet flow models could be used to quantify the instantaneous response of tide-driven ice shelf thinning on the ice flux across the grounding lines (similar to experiments by Reese et al., 2018). Such an approach, however, does not include longer term consequences. 
Antarctic tides are sensitive to changes in ice shelf geometry and sea levels, offering potential feedback on ice sheet relevant timescales. Antarctic tides can be interpreted as waves that propagate around the continent and barotropic ocean models show that shifts in sea levels, grounding line location and ice draft depth significantly alters their propagation and dissipation (Griffiths and Peltier, 2009; Rosier et al., 2014; Wilmes and Green, 2014). Ice shelf retreat in simulations by Rosier et al. (2014), for example, produces an overall increase of M2 dissipation by more than $40 \%$ (see their Table 1) and here we have shown that tides act to increase the conversion efficiency of ocean heat into ice shelf melting, which is also supported by idealized simulations by the study of Gwyther et al. (2016). On a more regional scale, tidal current strength is very sensitive to local changes in the water column thickness, which is set by ice shelf geometry and ocean depth (e.g. Galton-Fenzi et al., 2008; Mueller et al., 2012). Mueller et al. (2018) revealed that slight changes in the draft of the Filchner-Ronne Ice Shelf impacts tide driven melting in areas relevant for inland ice sheet dynamics. More drastic ice retreat in this region, however, might reduce the warm water intrusion under the Ronne Ice Shelf, as the M2 amphidromic point on the Weddell Sea migrates northward (Rosier et al., 2014) and our results suggest a connection between this point and the warm water intrusions. Potential positive and negative feedback between ice geometry, basal melting, and local as well as far field tides will need to be explored using coupled ocean-ice shelf-ice sheet models with Antarctic-wide coverage.

Likewise, regional changes in coastal hydrography due to tides might impact water mass transformation with consequences for global oceans and climate. Brine rejection in sea ice polynyas drives the formation of dense water, which has been linked to Antarctic Bottom Water (Purkey and Johnson, 2013) and the meridional overturning circulation (e.g. Jacobs, 2004). Deep water formation seems to be sensitive to local changes in the ocean, as recent studies show that glacial melt water can offset the densification by polynya activity (Williams et al., 2016; Silvano et al., 2018). Activating tides in our model changes depth average temperatures by up to $0.5^{\circ} \mathrm{C}$ in some locations and generates rectified currents with velocities of up to tens of centimetres per second. The relevance of these tidal currents and tidal-driven meltwater for water mass formation and transformation on the Antarctic continental shelf, and indeed on the global oceans and climate, is yet to be explored.

\section{Summary and Conclusion}

The modelling results presented here indicate that tides modulate Antarctic-wide ice shelf basal melting by various means:

- Tide induced warm water intrusions drive strong melting under the northwestern part of Ronne Ice Shelf and are likely driven by processes near the continental shelf break rather than ice-ocean interaction.

- Near the grounding zones of warm and cold water ice shelves, tidal currents control warm water advection and boundary layer exchange rates over sub-monthly timescales.

- These interactions act to strengthen buoyant meltwater plumes, which modulate according to the spring-neap tidal cycle on fortnightly timescales.

- Under some parts of the cold water ice shelves, tidal mixing governs ice-ocean interaction. 
The integrated impact on ice shelf basal mass loss and the continental shelf ocean temperature is small, but in opposing directions. Modelled basal mass loss increases only by $4 \%$, while continental shelf ocean temperatures drop by $0.04{ }^{\circ} \mathrm{C}$. This is in agreement with idealized modelling results of (Gwyther et al., 2016) and indicates a gain in the conversion efficiency of heat into melting. This efficiency is likely to change as Antarctic tides vary in strength over glaciation timescales (Griffiths and Peltier, 2009; Rosier et al., 2014; Wilmes and Green, 2014).

Regional variations, however, can be large with potential consequences for ice sheets and global oceans. Melt modulations at $4 \mathrm{~km}$ scale can exceed $500 \%$ and are often located near grounding zones, lateral boundaries and pinning points of cold water ice shelves. These regions are most valuable for the buttressing ability of ice shelves against tributary glacier discharge (Reese et al., 2018), but increased melt is often balanced by reduced melt or increased refreezing nearby, making it difficult to assess the overall impact without ice sheet modelling. Likewise, local changes in depth averaged ocean temperature on the continental shelf can exceed $0.5{ }^{\circ} \mathrm{C}$ and deep water formation driven by sea ice polynyas has been shown to be sensitive to such changes (Williams et al., 2016; Silvano et al., 2018).

Tides do not modulate melting at the ice front or below warm water ice shelves away from the grounding zone. In the model, tidal currents directly modulate velocities and temperatures close to the ice front only at a few locations, such as east of Ross Island (also observed by Arzeno et al., 2014). Likewise, fortnightly variations in $T^{*}$ close to the front only occur where tides drive warm water intrusions under the ice, for example in the northwestern part of Ronne Ice Shelf. In most places, however, frontal melting varies mostly on longer timescales and without fortnightly cycles, suggesting a strong buoyant regime that protects the ice from tidal influences (see also Malyarenko et al., 2019). Further, high melt rates in the AmundsenBellingshausen Seas are often related to warm water intrusions driven by non-tidal processes and, away from the grounding zone, the strength of these intrusions also controls ice-ocean interaction on sub-monthly timescales in our model.

In many regions, tide induced melt water affects ice-ocean interaction below other ice shelves downstream, highlighting the importance of ice shelf teleconnections. Regional studies suggest that ice shelf melt water can propagate downstream on the continental shelf (Jacobs and Giulivi, 2010; Nakayama et al., 2014a) and connect ice-ocean interaction between ice shelves (Gwyther et al., 2014; Silvano et al., 2018). Results presented here suggest that this is true for many regions around the continent. In particular, increased melting in the Weddell Sea is connected by a strong, tide induced current around the tip of the Antarctic Peninsula to decreased ocean temperatures in the Bellingshausen Sea. These findings highlight the importance of carefully selecting boundary locations and conditions in regional studies.

The absolute numbers presented in this study might be susceptible to model bias, but conclusions about the driving mechanisms are robust. No evaluation matrix for circum-Antarctic ice shelf-ocean models has been developed yet and, hence we present absolute estimates which should be taken with caution. Nevertheless, Antarctic-wide basal mass loss driven by tides is a valuable first estimate and our model has been proven successful in many regional and idealized applications (Galton-Fenzi et al., 2012; Cougnon et al., 2013; Gwyther et al., 2014, 2016), giving us confidence in our conclusions about the driving processes.

We conclude that tidal currents modulate Antarctic ice shelf melting not just by impacting boundary layer exchange rates, but also by means of vertical mixing, advection and continental shelf processes. Hence, parameterisations of tidal melting that 
account for boundary layer processes alone (as suggested by, e.g. Jourdain et al., 2019) will likely result in large biases in Antarctic-wide applications. Further, tidal strength changes with local and far field ice sheet retreat (e.g. Mueller et al., 2018; Rosier et al., 2014) and consequent changes in meltwater will impact ice-ocean interaction far downstream. Hence, models that aim to accurately predict future changes in ice shelf melting will need to explicitly resolve tides and have continent-wide coverage.

Code and data availability. The source code and configuration files used for the simulations described here are archived at http://doi.org/10. 5281/zenodo.3738985 (Richter, 2020a), while the maintained version is publicly available at https://github.com/kuechenrole/waom. The raw model output, grid files, atmospheric forcing, initial conditions, and northern boundary conditions can be obtained from the authors upon request. The data underlying the figures of this study are available at http://rdp.utas.edu.au/metadata/d34f18f9-a878-49cb-9ad5-b4d27e0c7b77. The Python and Matlab scripts used to generate the grid and forcing files and to perform the analysis on the model output are archived at http://doi.org/10.5281/zenodo.3738998 (Richter, 2020b) and the maintained version of these scripts is publicly available at https://github. com/kuechenrole/antarctic_melting.

\section{Appendix A: Tide-Driven Ice Shelf Basal Mass Loss}


Table A1. Ice shelf average mass loss due to tides. For 139 individual ice shelves the table shows the area, melt rate $\left(w_{b}\right)$ and Basal Mass Loss (BML) of the run with tides as well as its difference to the run without tides in absolute (e.g. $w_{b}$ tides $-w_{b}$ no-tides) and relative $\left(\left(w_{b \text { tides }}-w_{b \text { no-tides }}\right) / w_{b}\right.$ no-tides $)$ terms. Ice Shelf boundaries have been taken from the MEaSURES dataset (Mouginot et al., 2016).

\begin{tabular}{|c|c|c|c|c|c|c|}
\hline Ice Shelf & $\begin{array}{c}\text { Area } \\
\left(10^{3} \mathrm{~km}^{2}\right)\end{array}$ & $\begin{array}{c}w_{b} \\
(\mathbf{m} / \mathbf{y r})\end{array}$ & $\underset{(\mathbf{G t} / \mathbf{y r})}{\mathbf{B M L}}$ & $\begin{array}{c}w_{b} \\
\text { Difference } \\
(\mathbf{m} / \mathbf{y r})\end{array}$ & $\begin{array}{c}\text { BML } \\
\text { Difference } \\
(\mathbf{G t} / \mathbf{y r})\end{array}$ & $\begin{array}{c}w_{b} \text { and BML } \\
\text { Relative } \\
\text { Difference } \\
(\%)\end{array}$ \\
\hline Abbot & 29.74 & 2.57 & 70.09 & 0.14 & 3.95 & 5.97 \\
\hline Abbot 1 & 0.24 & 1.11 & 0.24 & -0.05 & -0.01 & -4.50 \\
\hline Abbot 2 & 0.34 & 0.92 & 0.28 & -0.02 & -0.01 & -2.23 \\
\hline Abbot 3 & 0.35 & 0.39 & 0.13 & -0.01 & 0.00 & -2.31 \\
\hline Abbot 4 & 0.43 & 1.34 & 0.53 & -0.02 & -0.01 & -1.53 \\
\hline Abbot 5 & 0.54 & 1.23 & 0.61 & 0.03 & 0.02 & 2.77 \\
\hline Abbot 6 & 0.26 & 0.65 & 0.15 & -0.01 & 0.00 & -1.91 \\
\hline Ainsworth & 0.12 & 0.40 & 0.05 & 0.00 & 0.00 & -0.20 \\
\hline Alison & 0.08 & 6.66 & 0.49 & -0.37 & -0.03 & -5.25 \\
\hline Amery & 59.85 & 0.18 & 9.68 & 0.03 & 1.59 & 19.73 \\
\hline Astrolabe & 0.11 & 0.72 & 0.07 & -0.07 & -0.01 & -8.80 \\
\hline Atka & 2.14 & 1.34 & 2.62 & 0.12 & 0.23 & 9.50 \\
\hline Aviator & 0.92 & 0.26 & 0.22 & 0.03 & 0.02 & 11.48 \\
\hline Bach & 4.61 & 3.49 & 14.74 & 1.11 & 4.70 & 46.80 \\
\hline Baudouin & 33.40 & 0.74 & 22.62 & 0.18 & 5.55 & 32.53 \\
\hline Borchgrevink & 21.11 & 1.51 & 29.15 & 0.12 & 2.27 & 8.46 \\
\hline Brahms & 0.25 & 2.00 & 0.47 & -0.04 & -0.01 & -2.15 \\
\hline Brunt Stancomb & 36.66 & 1.03 & 34.63 & 0.05 & 1.65 & 4.99 \\
\hline Campbell & 0.11 & 0.73 & 0.08 & 0.00 & 0.00 & 0.09 \\
\hline Cheetham & 0.11 & 0.11 & 0.01 & 0.00 & 0.00 & 0.76 \\
\hline Chugunov & 0.05 & 0.66 & 0.03 & 0.12 & 0.01 & 22.72 \\
\hline Conger Glenzer & 1.63 & 3.08 & 4.58 & 0.72 & 1.08 & 30.78 \\
\hline Cook & 3.63 & 3.72 & 12.38 & -0.18 & -0.61 & -4.71 \\
\hline Cosgrove & 2.94 & 3.40 & 9.16 & 0.13 & 0.35 & 4.00 \\
\hline Crosson & 3.11 & 0.69 & 1.98 & -0.05 & -0.14 & -6.59 \\
\hline Deakin & 0.09 & 2.60 & 0.22 & -0.28 & -0.02 & -9.64 \\
\hline
\end{tabular}


continued from previous page

Ice Shelf

\section{Area} $\left(10^{3} \mathrm{~km}^{2}\right)$

$w_{b} \quad$ BML

$\underset{(\mathrm{Gt} / \mathrm{yr})}{\boldsymbol{w}_{b}}$

BML $(\mathbf{m} / \mathbf{y r})$

Difference
$(\mathrm{m} / \mathrm{yr})$

Difference
(Gt/yr)

$w_{b}$ and BML

Relative

Difference

(\%)

\begin{tabular}{|c|c|c|c|c|c|c|}
\hline Dennistoun & 0.13 & 1.40 & 0.16 & 0.82 & 0.10 & 143.73 \\
\hline Dibble & 1.56 & 2.81 & 4.01 & 0.12 & 0.18 & 4.59 \\
\hline Dotson & 5.16 & 0.70 & 3.33 & -0.04 & -0.18 & -5.21 \\
\hline Drury & 0.09 & 1.56 & 0.13 & 0.35 & 0.03 & 29.10 \\
\hline Drygalski & 2.45 & 0.73 & 1.63 & 0.06 & 0.13 & 8.72 \\
\hline Edward VIII & 0.43 & 0.56 & 0.22 & -0.03 & -0.01 & -4.32 \\
\hline Ekstrom & 6.90 & 1.06 & 6.69 & 0.23 & 1.45 & 27.69 \\
\hline Erebus & 0.05 & 0.25 & 0.01 & 0.03 & 0.00 & 14.75 \\
\hline Ferrigno & 0.18 & 6.43 & 1.04 & -0.49 & -0.08 & -7.02 \\
\hline Filchner & 102.07 & 0.06 & 5.51 & -0.09 & -8.31 & -60.14 \\
\hline Fimbul & 40.69 & 1.73 & 64.31 & -0.19 & -6.96 & -9.77 \\
\hline Fisher & 0.19 & 0.83 & 0.14 & 0.03 & 0.00 & 3.13 \\
\hline Fitzgerald & 0.37 & 0.29 & 0.10 & 0.05 & 0.02 & 22.97 \\
\hline Flatnes & 0.09 & 0.53 & 0.05 & 0.03 & 0.00 & 6.22 \\
\hline Fox Glacier & 0.08 & 3.33 & 0.23 & -0.06 & 0.00 & -1.85 \\
\hline Francais & 0.09 & 1.56 & 0.13 & -0.15 & -0.01 & -8.80 \\
\hline Frost & 0.26 & 2.33 & 0.56 & -0.95 & -0.23 & -28.88 \\
\hline Garfield & 0.06 & 0.46 & 0.03 & 0.02 & 0.00 & 4.00 \\
\hline Geikie Inlet & 0.33 & 0.09 & 0.03 & -0.01 & 0.00 & -7.72 \\
\hline George VI & 23.15 & 7.76 & 164.50 & -0.20 & -4.28 & -2.53 \\
\hline Getz & 33.50 & 1.95 & 59.97 & 0.17 & 5.33 & 9.76 \\
\hline Getz 1 & 0.60 & 1.09 & 0.59 & -0.17 & -0.09 & -13.22 \\
\hline Gillet & 0.17 & 0.90 & 0.14 & 0.33 & 0.05 & 56.87 \\
\hline Hamilton & 0.21 & 2.88 & 0.56 & -0.46 & -0.09 & -13.65 \\
\hline Hannan & 0.40 & 0.30 & 0.11 & -0.01 & 0.00 & -2.17 \\
\hline Harbord Glacier & 0.10 & 0.14 & 0.01 & 0.01 & 0.00 & 10.54 \\
\hline Helen & 0.35 & 1.98 & 0.64 & -0.05 & -0.02 & -2.60 \\
\hline Holmes & 2.38 & 1.56 & 3.40 & -0.73 & -1.59 & -31.87 \\
\hline Holt & 0.08 & 1.11 & 0.08 & 0.28 & 0.02 & 33.78 \\
\hline Horn Bluff & 0.17 & 1.67 & 0.26 & 0.07 & 0.01 & 4.17 \\
\hline Hoseason & 0.14 & 1.15 & 0.15 & 0.03 & 0.00 & 2.32 \\
\hline Hull & 0.19 & 0.97 & 0.17 & 0.02 & 0.00 & 2.21 \\
\hline Ironside & 0.10 & 0.20 & 0.02 & 0.04 & 0.00 & 21.93 \\
\hline
\end{tabular}


continued from previous page

Ice Shelf

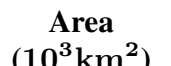

$\begin{array}{cc}w_{b} & \text { BML } \\ (\mathbf{m} / \mathbf{y r}) & (\mathbf{G t} / \mathbf{y r})\end{array}$

$\underset{(\mathrm{Gt} / \mathrm{yr})}{\boldsymbol{w}_{b}}$

$\underset{(\mathbf{m} / \mathbf{y r})}{w_{b}}$

BML

Difference

(Gt/yr)

$w_{b}$ and BML

Relative

Difference

(\%)

\begin{tabular}{|c|c|c|c|c|c|c|}
\hline Jackson & 0.08 & 0.95 & 0.07 & 0.12 & 0.01 & 14.47 \\
\hline Jelbart & 10.83 & 1.10 & 10.96 & -0.09 & -0.90 & -7.58 \\
\hline Land & 0.68 & 3.07 & 1.92 & 1.62 & 1.02 & 112.06 \\
\hline LarsenA & 0.79 & 0.60 & 0.44 & 0.38 & 0.27 & 164.36 \\
\hline LarsenB & 2.13 & 0.43 & 0.83 & 0.03 & 0.05 & 6.82 \\
\hline LarsenC & 46.50 & 0.24 & 10.17 & 0.01 & 0.50 & 5.20 \\
\hline LarsenD & 21.84 & 0.30 & 5.96 & 0.09 & 1.83 & 44.41 \\
\hline LarsenD 1 & 0.06 & 0.23 & 0.01 & -0.13 & -0.01 & -35.59 \\
\hline LarsenE & 1.25 & 0.68 & 0.78 & 0.29 & 0.33 & 74.79 \\
\hline LarsenF & 0.87 & 0.34 & 0.27 & 0.12 & 0.09 & 51.86 \\
\hline LarsenG & 0.47 & 0.17 & 0.07 & -0.05 & -0.02 & -21.45 \\
\hline Lauritzen & 0.60 & 2.02 & 1.10 & 0.40 & 0.22 & 24.98 \\
\hline Lazarev & 8.73 & 0.73 & 5.80 & -0.01 & -0.10 & -1.74 \\
\hline Lillie & 0.86 & 2.58 & 2.02 & 0.26 & 0.21 & 11.37 \\
\hline Mariner & 2.73 & 0.69 & 1.73 & 0.36 & 0.90 & 108.98 \\
\hline Marret & 0.05 & 2.70 & 0.11 & -0.37 & -0.02 & -12.21 \\
\hline Matusevitch & 0.30 & 4.61 & 1.26 & 1.03 & 0.28 & 28.72 \\
\hline May Glacier & 0.32 & 2.53 & 0.75 & 0.16 & 0.05 & 6.77 \\
\hline Mendelssohn & 0.48 & 3.76 & 1.64 & -0.22 & -0.09 & -5.41 \\
\hline Mertz & 5.68 & 1.40 & 7.27 & 0.41 & 2.13 & 41.37 \\
\hline Moscow Uni. & 6.10 & 1.38 & 7.72 & -0.24 & -1.31 & -14.54 \\
\hline Moubray & 0.18 & 0.27 & 0.04 & 0.15 & 0.02 & 132.46 \\
\hline Mulebreen & 0.34 & 0.52 & 0.16 & -0.03 & -0.01 & -4.82 \\
\hline Nansen & 1.98 & 0.01 & 0.02 & -0.01 & -0.02 & -48.74 \\
\hline Nickerson & 6.83 & 3.67 & 22.93 & -0.57 & -3.55 & -13.42 \\
\hline Ninnis & 2.03 & 2.82 & 5.25 & -0.04 & -0.07 & -1.23 \\
\hline Nivl & 7.53 & 0.40 & 2.79 & 0.09 & 0.62 & 28.80 \\
\hline Noll & 0.16 & 4.00 & 0.58 & 1.03 & 0.15 & 34.55 \\
\hline Nordenskjold & 0.29 & 0.30 & 0.08 & 0.02 & 0.00 & 6.55 \\
\hline Parker & 0.11 & 0.11 & 0.01 & 0.00 & 0.00 & 4.78 \\
\hline Philbin Inlet & 0.11 & 0.47 & 0.05 & -0.04 & 0.00 & -8.37 \\
\hline Pine Island & 5.96 & 7.02 & 38.32 & -0.33 & -1.78 & -4.44 \\
\hline Porter & 0.08 & 2.04 & 0.14 & -0.04 & 0.00 & -1.71 \\
\hline
\end{tabular}


continued from previous page

\begin{tabular}{|c|c|c|c|c|c|c|}
\hline Ice Shelf & $\begin{array}{c}\text { Area } \\
\left(10^{3} \mathrm{~km}^{2}\right)\end{array}$ & $\begin{array}{c}w_{b} \\
(\mathbf{m} / \mathbf{y r})\end{array}$ & $\begin{array}{c}\text { BML } \\
(\mathbf{G t} / \mathbf{y r})\end{array}$ & $\begin{array}{c}w_{b} \\
\text { Difference } \\
(\mathbf{m} / \mathbf{y r})\end{array}$ & $\begin{array}{c}\text { BML } \\
\text { Difference } \\
(\mathbf{G t} / \mathbf{y r})\end{array}$ & $\begin{array}{c}w_{b} \text { and BML } \\
\text { Relative } \\
\text { Difference } \\
(\%)\end{array}$ \\
\hline Pourquoi Pas & 0.20 & 4.91 & 0.90 & -0.44 & -0.08 & -8.25 \\
\hline Prince Harald & 5.66 & 1.27 & 6.61 & -0.04 & -0.23 & -3.34 \\
\hline Publications & 1.62 & 0.62 & 0.93 & 0.07 & 0.10 & 12.24 \\
\hline Quar & 2.29 & 1.71 & 3.59 & -0.08 & -0.18 & -4.66 \\
\hline Rayner Thyer & 0.62 & 0.28 & 0.16 & 0.03 & 0.02 & 13.32 \\
\hline Rennick & 3.32 & 0.25 & 0.77 & 0.08 & 0.25 & 48.91 \\
\hline Richter & 0.15 & 7.91 & 1.07 & -0.80 & -0.11 & -9.19 \\
\hline Riiser-Larsen & 43.53 & 0.93 & 37.11 & 0.04 & 1.63 & 4.61 \\
\hline Ronne & 333.48 & 0.26 & 78.32 & 0.14 & 43.93 & 127.75 \\
\hline Ross East & 191.24 & 0.17 & 29.30 & 0.01 & 2.04 & 7.47 \\
\hline Ross West & 300.76 & 0.16 & 43.57 & 0.04 & 11.41 & 35.46 \\
\hline Rund Bay & 0.14 & 1.33 & 0.17 & -0.08 & -0.01 & -5.60 \\
\hline Shackleton & 26.43 & 0.80 & 19.37 & 0.10 & 2.50 & 14.84 \\
\hline Shirase & 0.74 & 1.33 & 0.91 & -0.01 & -0.01 & -1.10 \\
\hline Skallen & 0.06 & 0.30 & 0.02 & 0.01 & 0.00 & 2.65 \\
\hline Slava & 0.38 & 0.75 & 0.26 & 0.03 & 0.01 & 3.61 \\
\hline Sorsdal & 0.19 & 1.24 & 0.21 & 0.03 & 0.01 & 2.79 \\
\hline Stange & 8.29 & 2.50 & 18.98 & 0.24 & 1.83 & 10.66 \\
\hline Sulzberger & 12.47 & 7.81 & 89.24 & -0.96 & -10.97 & -10.94 \\
\hline Suter & 0.05 & 0.11 & 0.00 & 0.07 & 0.00 & 172.75 \\
\hline Suvorov & 0.22 & 1.02 & 0.21 & 0.18 & 0.04 & 20.85 \\
\hline Swinburne & 0.93 & 12.74 & 10.88 & -0.92 & -0.78 & -6.71 \\
\hline Thwaites & 4.51 & 7.36 & 30.36 & -0.54 & -2.22 & -6.82 \\
\hline Tinker & 0.15 & 0.03 & 0.00 & -0.01 & 0.00 & -13.99 \\
\hline Totten & 6.14 & 1.72 & 9.66 & 0.27 & 1.50 & 18.39 \\
\hline Tracy Tremenchus & 2.81 & 0.86 & 2.20 & 0.02 & 0.05 & 2.46 \\
\hline Tucker & 0.46 & 0.75 & 0.32 & 0.42 & 0.18 & 125.72 \\
\hline Underwood & 0.20 & 2.26 & 0.42 & -0.09 & -0.02 & -3.75 \\
\hline Utsikkar & 0.09 & 0.73 & 0.06 & 0.01 & 0.00 & 1.51 \\
\hline Venable & 3.31 & 4.65 & 14.07 & -0.20 & -0.62 & -4.20 \\
\hline Verdi & 0.14 & 5.41 & 0.71 & -0.13 & -0.02 & -2.29 \\
\hline Vigrid & 2.10 & 1.07 & 2.07 & 0.03 & 0.06 & 3.16 \\
\hline Vincennes Bay & 1.14 & 1.99 & 2.08 & -0.06 & -0.06 & -2.80 \\
\hline
\end{tabular}


continued from previous page

Ice Shelf

$$
\text { Area }
$$
$\left(10^{3} \mathrm{~km}^{2}\right)$

$w_{b}$
$(\mathbf{m} / \mathbf{y r})$

BML

(Gt/yr)

BML

$w_{b}$ and BML

Difference

(Gt/yr)

Relative

Difference

(\%)

$\begin{array}{lcccccc}\text { Voyeykov } & 0.69 & 1.66 & 1.06 & -0.07 & -0.05 & -4.29 \\ \text { Walgreen Coast 1 } & 0.11 & 5.95 & 0.62 & -0.55 & -0.06 & -8.50 \\ \text { Walgreen Coast 2 } & 0.03 & 2.84 & 0.08 & -0.40 & -0.01 & -12.40 \\ \text { Watt Bay } & 0.11 & 0.68 & 0.07 & -0.11 & -0.01 & -13.83 \\ \text { West } & 15.86 & 1.69 & 24.58 & 0.09 & 1.35 & 5.79 \\ \text { Whittle } & 0.11 & 1.06 & 0.10 & -0.28 & -0.03 & -20.75 \\ \text { Wilkins } & 13.04 & 1.31 & 15.61 & -0.06 & -0.76 & -4.65 \\ \text { Williamson } & 0.20 & 2.67 & 0.49 & -0.24 & -0.04 & -8.14 \\ \text { Wilma-Robert- } & & & & & & \\ \text { Downer } & 0.91 & 0.50 & 0.42 & -0.03 & -0.03 & -5.72 \\ \text { Withrow } & 0.72 & 4.09 & 2.70 & -0.83 & -0.55 & -16.94 \\ \text { Wordie (Harriott) } & 0.09 & 0.12 & 0.01 & -0.02 & 0.00 & -12.46 \\ \text { Wordie (Prospect) } & 0.20 & 0.19 & 0.03 & 0.00 & 0.00 & -1.19 \\ \text { Wylde } & 0.18 & 0.22 & 0.04 & 0.08 & 0.01 & 58.21 \\ \text { Zubchatyy } & 0.33 & 0.80 & 0.24 & -0.07 & -0.02 & -7.50\end{array}$


Author contributions. Ole Richter conceived and designed the experiments with contributions from all co-authors. Ole Richter performed the simulations. Ole Richter, David E. Gwyther and Benjamin K. Galton-Fenzi analysed the data, whereby David E. Gwyther also contributed analysis tools. Ole Richter prepared the manuscript with contributions from all co-authors.

Competing interests. The authors declare that they have no conflict of interest.

Acknowledgements. This research was supported by scholarships from the Australian Government and the Australian Research Council's Special Research Initiative for the Antarctic Gateway Partnership SRI40300001. Computational resources were provided by the NCI National 385 Facility at the Australian National University, through awards under the Merit Allocation Scheme. We would like to thank Richard Coleman for his valuable comments on the manuscript and Just Berkhout for his excellent IT support. 


\section{References}

Arzeno, I. B., Beardsley, R. C., Limeburner, R., Owens, B., Padman, L., Springer, S. R., Stewart, C. L., and Williams, M. J. M.: Ocean variability contributing to basal melt rate near the ice front of Ross Ice Shelf, Antarctica, Journal of Geophysical Research: Oceans, 119, 4214-4233, https://doi.org/10.1002/2014JC009792, https://agupubs.onlinelibrary.wiley.com/doi/abs/10.1002/2014JC009792, 2014.

Asay-Davis, X. S., Jourdain, N. C., and Nakayama, Y.: Developments in Simulating and Parameterizing Interactions Between the Southern Ocean and the Antarctic Ice Sheet, Current Climate Change Reports, 3, 316-329, https://doi.org/10.1007/s40641-017-0071-0, https://link. springer.com/article/10.1007/s40641-017-0071-0, 2017.

Begeman, C. B., Tulaczyk, S. M., Marsh, O. J., Mikucki, J. A., Stanton, T. P., Hodson, T. O., Siegfried, M. R., Powell, R. D., Christianson, K., and King, M. A.: Ocean Stratification and Low Melt Rates at the Ross Ice Shelf Grounding Zone, Journal of Geophysical Research: Oceans, 123, 7438-7452, https://doi.org/10.1029/2018JC013987, https://agupubs.onlinelibrary.wiley.com/doi/abs/10.1029/ 2018JC013987, 2018.

Bronselaer, B., Winton, M., Griffies, S. M., Hurlin, W. J., Rodgers, K. B., Sergienko, O. V., Stouffer, R. J., and Russell, J. L.: Change in future climate due to Antarctic meltwater, Nature, 564, 53, https://doi.org/10.1038/s41586-018-0712-z, https://www.nature.com/articles/ s41586-018-0712-z, 2018.

Cougnon, E. A., Galton-Fenzi, B. K., Meijers, A. J. S., and Legrésy, B.: Modeling interannual dense shelf water export in the region of the Mertz Glacier Tongue (1992-2007), Journal of Geophysical Research: Oceans, 118, 5858-5872, https://doi.org/10.1002/2013JC008790, https://agupubs.onlinelibrary.wiley.com/doi/abs/10.1002/2013JC008790, 2013.

Dee, D. P., Uppala, S. M., Simmons, A. J., Berrisford, P., Poli, P., Kobayashi, S., Andrae, U., Balmaseda, M. A., Balsamo, G., Bauer, P., Bechtold, P., Beljaars, A. C. M., Berg, L. v. d., Bidlot, J., Bormann, N., Delsol, C., Dragani, R., Fuentes, M., Geer, A. J., Haimberger, L., Healy, S. B., Hersbach, H., Hólm, E. V., Isaksen, L., Kållberg, P., Köhler, M., Matricardi, M., McNally, A. P., Monge-Sanz, B. M., Morcrette, J.-J., Park, B.-K., Peubey, C., Rosnay, P. d., Tavolato, C., Thépaut, J.-N., and Vitart, F.: The ERA-Interim reanalysis: configuration and performance of the data assimilation system, Quarterly Journal of the Royal Meteorological Society, 137, 553-597, https://doi.org/10.1002/qj.828, https://rmets.onlinelibrary.wiley.com/doi/abs/10.1002/qj.828, 2011.

Dinniman, M. S., Asay-Davis, X. S., Galton-Fenzi, B. K., Holland, P. R., Jenkins, A., and Timmermann, R.: Modeling Ice Shelf/Ocean Interaction in Antarctica: A Review, Oceanography, 29, 144-153, https://doi.org/10.5670/oceanog.2016.106, https://tos.org/oceanography/ article/modeling-ice-shelf-ocean-interaction-in-antarctica-a-review, 2016.

Egbert, G. D. and Erofeeva, S. Y.: Efficient Inverse Modeling of Barotropic Ocean Tides, Journal of Atmospheric and Oceanic Technology, 19, 183-204, https://doi.org/10.1175/1520-0426(2002)019<0183:EIMOBO>2.0.CO;2, https://journals.ametsoc.org/doi/full/10.1175/ 1520-0426\%282002\%29019\%3C0183\%3AEIMOBO\%3E2.0.CO\%3B2, 2002.

Elsner, J. B. and Tsonis, A. A.: Singular Spectrum Analysis: A New Tool in Time Series Analysis, Springer US, https://doi.org/10.1007/9781-4757-2514-8, https://www.springer.com/gp/book/9780306454721, 1996.

Foldvik, A., Gammelsrød, T., Slotsvik, N., and Tørresen, T.: Oceanographic conditions on the Weddell Sea Shelf during the German Antarctic Expedition 1979/80, Polar Research, 3, 209-226, https://doi.org/10.3402/polar.v3i2.6953, https://polarresearch.net/index.php/polar/ article/view/2526, 1985.

Foldvik, A., Middleton, J. H., and Foster, T. D.: The tides of the southern Weddell Sea, Deep Sea Research Part A. Oceanographic Research Papers, 37, 1345-1362, https://doi.org/10.1016/0198-0149(90)90047-Y, http://www.sciencedirect.com/science/article/ pii/019801499090047Y, 1990. 
Fretwell, P., Pritchard, H. D., Vaughan, D. G., Bamber, J. L., Barrand, N. E., Bell, R., Bianchi, C., Bingham, R. G., Blankenship, D. D.,

Casassa, G., Catania, G., Callens, D., Conway, H., Cook, A. J., Corr, H. F. J., Damaske, D., Damm, V., Ferraccioli, F., Forsberg, R., Fujita, S., Gim, Y., Gogineni, P., Griggs, J. A., Hindmarsh, R. C. A., Holmlund, P., Holt, J. W., Jacobel, R. W., Jenkins, A., Jokat, W., Jordan, T., King, E. C., Kohler, J., Krabill, W., Riger-Kusk, M., Langley, K. A., Leitchenkov, G., Leuschen, C., Luyendyk, B. P., Matsuoka, K., Mouginot, J., Nitsche, F. O., Nogi, Y., Nost, O. A., Popov, S. V., Rignot, E., Rippin, D. M., Rivera, A., Roberts, J., Ross, N., Siegert, M. J., Smith, A. M., Steinhage, D., Studinger, M., Sun, B., Tinto, B. K., Welch, B. C., Wilson, D., Young, D. A., Xiangbin, C., and Zirizzotti, A.: Bedmap2: improved ice bed, surface and thickness datasets for Antarctica, The Cryosphere, 7, 375-393, https://doi.org/https://doi.org/10.5194/tc-7-375-2013, https://www.the-cryosphere.net/7/375/2013/, 2013.

Galton-Fenzi, B. K., Maraldi, C., Coleman, R., and Hunter, J.: The cavity under the Amery Ice Shelf, East Antarctica, Journal of Glaciology, 54, 881-887, https://doi.org/10.3189/002214308787779898, https://www.cambridge.org/core/journals/journal-of-glaciology/article/ cavity-under-the-amery-ice-shelf-east-antarctica/D4F660A6EFACBB9047540B63190B3D57, 2008.

Galton-Fenzi, B. K., Hunter, J. R., Coleman, R., Marsland, S. J., and Warner, R. C.: Modeling the basal melting and marine ice accretion of the Amery Ice Shelf, Journal of Geophysical Research: Oceans, 117, https://doi.org/10.1029/2012JC008214, https://agupubs.onlinelibrary. wiley.com/doi/abs/10.1029/2012JC008214, 2012.

Gammelsrod, T. and Slotsvik, N.: Hydrographic and Current Measurements in the Southern Weddell Sea 1979/80, Polarforschung, https: //epic.awi.de/id/eprint/28128/, 1981.

Griffiths, S. D. and Peltier, W. R.: Modeling of Polar Ocean Tides at the Last Glacial Maximum: Amplification, Sensitivity, and Climatological Implications, Journal of Climate, 22, 2905-2924, https://doi.org/10.1175/2008JCLI2540.1, https://journals.ametsoc.org/doi/abs/10. 1175/2008JCLI2540.1, 2009.

Gudmundsson, G. H.: Ice-shelf buttressing and the stability of marine ice sheets, The Cryosphere, 7, 647-655, https://doi.org/https://doi.org/10.5194/tc-7-647-2013, https://www.the-cryosphere.net/7/647/2013/, 2013.

Gwyther, D. E., Galton-Fenzi, B. K., Hunter, J. R., and Roberts, J. L.: Simulated melt rates for the Totten and Dalton ice shelves, Ocean Science, 10, 267-279, https://doi.org/https://doi.org/10.5194/os-10-267-2014, https://www.ocean-sci.net/10/267/2014/, 2014.

Gwyther, D. E., Cougnon, E. A., Galton-Fenzi, B. K., Roberts, J. L., Hunter, J. R., and Dinniman, M. S.: Modelling the response of ice shelf basal melting to different ocean cavity environmental regimes, Annals of Glaciology, 57, 131-141, https://doi.org/10.1017/aog.2016.31, https://www.cambridge.org/core/product/identifier/S0260305516000318/type/journal_article, 2016.

Gwyther, D. E., O’Kane, T. J., Galton-Fenzi, B. K., Monselesan, D. P., and Greenbaum, J. S.: Intrinsic processes drive variability in basal melting of the Totten Glacier Ice Shelf, Nature Communications, 9, 3141, https://doi.org/10.1038/s41467-018-05618-2, https://www. nature.com/articles/s41467-018-05618-2, 2018.

Hellmer, H. H. and Olbers, D. J.: A two-dimensional model for the thermohaline circulation under an ice shelf, Antarctic Science, 1, 325-336, https://doi.org/10.1017/S0954102089000490, https://www.cambridge.org/core/journals/antarctic-science/article/ twodimensional-model-for-the-thermohaline-circulation-under-an-ice-shelf/DCB7E3D1C510375CD52CBBD6C42A3993\#, 1989.

Holland, D. M. and Jenkins, A.: Modeling Thermodynamic Ice-Ocean Interactions at the Base of an Ice Shelf, Journal of Physical Oceanography, 29, 1787-1800, https://doi.org/10.1175/1520-0485(1999)029<1787:MTIOIA>2.0.CO;2, https://journals.ametsoc.org/doi/full/10. 1175/1520-0485\%281999\%29029\%3C1787\%3AMTIOIA\%3E2.0.CO\%3B2, 1999.

Jacobs, S. S.: Bottom water production and its links with the thermohaline circulation, Antarctic Science, 16, 427437, https://doi.org/10.1017/S095410200400224X, https://www.cambridge.org/core/journals/antarctic-science/article/ bottom-water-production-and-its-links-with-the-thermohaline-circulation/9C29FAEDC0136B2C616B8E7491671916, 2004. 
Jacobs, S. S. and Giulivi, C. F.: Large Multidecadal Salinity Trends near the Pacific-Antarctic Continental Margin, Journal of Climate, 23, 4508-4524, https://doi.org/10.1175/2010JCLI3284.1, http://journals.ametsoc.org/doi/abs/10.1175/2010JCLI3284.1, 2010.

Jacobs, S. S., Helmer, H. H., Doake, C. S. M., Jenkins, A., and Frolich, R. M.: Melting of ice shelves and the mass balance of Antarctica, Journal of Glaciology, 38, 375-387, https://doi.org/10.3189/S0022143000002252, https://www.cambridge.org/core/journals/ journal-of-glaciology/article/melting-of-ice-shelves-and-the-mass-balance-of-antarctica/B4841D1BF7AD77C197F8FDA33BE9936C, 1992.

Jenkins, A., Nicholls, K. W., and Corr, H. F. J.: Observation and Parameterization of Ablation at the Base of Ronne Ice Shelf, Antarctica, Journal of Physical Oceanography, 40, 2298-2312, https://doi.org/10.1175/2010JPO4317.1, https://journals.ametsoc.org/doi/full/10.1175/ 2010JPO4317.1, 2010.

Jourdain, N. C., Molines, J.-M., Le Sommer, J., Mathiot, P., Chanut, J., de Lavergne, C., and Madec, G.: Simulating or prescribing the influence of tides on the Amundsen Sea ice shelves, Ocean Modelling, 133, 44-55, https://doi.org/10.1016/j.ocemod.2018.11.001, https: //linkinghub.elsevier.com/retrieve/pii/S1463500318301203, 2019.

Kimura, S., Nicholls, K. W., and Venables, E.: Estimation of Ice Shelf Melt Rate in the Presence of a Thermohaline Staircase, Journal of Physical Oceanography, 45, 133-148, https://doi.org/10.1175/JPO-D-14-0106.1, https://journals.ametsoc.org/doi/full/10.1175/ JPO-D-14-0106.1, 2014.

King, M. A. and Padman, L.: Accuracy assessment of ocean tide models around Antarctica, Geophysical Research Letters, 32, https://doi.org/10.1029/2005GL023901, https://agupubs.onlinelibrary.wiley.com/doi/abs/10.1029/2005GL023901, 2005.

Lewis, E. L. and Perkin, R. G.: Ice pumps and their rates, Journal of Geophysical Research: Oceans, 91, 11756-11762, https://doi.org/10.1029/JC091iC10p11756, https://agupubs.onlinelibrary.wiley.com/doi/abs/10.1029/JC091iC10p11756, 1986.

Liu, Y., Moore, J. C., Cheng, X., Gladstone, R. M., Bassis, J. N., Liu, H., Wen, J., and Hui, F.: Ocean-driven thinning enhances iceberg calving and retreat of Antarctic ice shelves, Proceedings of the National Academy of Sciences, 112, 3263-3268, https://doi.org/10.1073/pnas.1415137112, http://www.pnas.org/content/112/11/3263, 2015.

Llanillo, P. J., Aiken, C. M., Cordero, R. R., Damiani, A., Sepúlveda, E., and Fernández-Gómez, B.: Oceanographic Variability induced by Tides, the Intraseasonal Cycle and Warm Subsurface Water intrusions in Maxwell Bay, King George Island (West-Antarctica), Scientific Reports, 9, 1-17, https://doi.org/10.1038/s41598-019-54875-8, https://www.nature.com/articles/s41598-019-54875-8, 2019.

Loder, J. W.: Topographic Rectification of Tidal Currents on the Sides of Georges Bank, Journal of Physical Oceanography, 10, 1399-1416, https://doi.org/10.1175/1520-0485(1980)010<1399:TROTCO>2.0.CO;2, https://journals.ametsoc.org/doi/abs/10.1175/ 1520-0485\%281980\%29010\%3C1399\%3ATROTCO\%3Е2.0.CO\%3B2, 1980.

MacAyeal, D. R.: Thermohaline circulation below the Ross Ice Shelf: A consequence of tidally induced vertical mixing and basal melting, Journal of Geophysical Research: Oceans, 89, 597-606, https://doi.org/10.1029/JC089iC01p00597, https://agupubs.onlinelibrary.wiley. com/doi/abs/10.1029/JC089iC01p00597, 1984

MacAyeal, D. R.: Tidal Rectification Below the Ross Ice Shelf, Antarctica, Oceanology of the Antarctic Continental Shelf, https://agupubs. onlinelibrary.wiley.com/doi/10.1029/AR043p0109, 1985.

495 Mack, S. L., Dinniman, M. S., McGillicuddy, D. J., Sedwick, P. N., and Klinck, J. M.: Dissolved iron transport pathways in the Ross Sea: Influence of tides and horizontal resolution in a regional ocean model, Journal of Marine Systems, 166, 73-86, https://doi.org/10.1016/j.jmarsys.2016.10.008, http://www.sciencedirect.com/science/article/pii/S0924796316303360, 2017. 
Makinson, K. and Nicholls, K. W.: Modeling tidal currents beneath Filchner-Ronne Ice Shelf and on the adjacent continental shelf: Their effect on mixing and transport, Journal of Geophysical Research: Oceans, 104, 13 449-13 465, https://doi.org/10.1029/1999JC900008, https://agupubs.onlinelibrary.wiley.com/doi/abs/10.1029/1999JC900008, 1999.

Makinson, K., Holland, P. R., Jenkins, A., Nicholls, K. W., and Holland, D. M.: Influence of tides on melting and freezing beneath FilchnerRonne Ice Shelf, Antarctica, Geophysical Research Letters, 38, https://doi.org/10.1029/2010GL046462, https://agupubs.onlinelibrary. wiley.com/doi/abs/10.1029/2010GL046462, 2011.

Malyarenko, A., Robinson, N. J., Williams, M. J. M., and Langhorne, P. J.: A Wedge Mechanism for Summer Surface Water Inflow Into the Ross Ice Shelf Cavity, Journal of Geophysical Research: Oceans, 124, 1196-1214, https://doi.org/10.1029/2018JC014594, https: //agupubs.onlinelibrary.wiley.com/doi/abs/10.1029/2018JC014594, 2019.

Mazloff, M. R., Heimbach, P., and Wunsch, C.: An Eddy-Permitting Southern Ocean State Estimate, Journal of Physical Oceanography, 40, 880-899, https://doi.org/10.1175/2009JPO4236.1, https://journals.ametsoc.org/doi/full/10.1175/2009JPO4236.1, 2010.

McPhee, M. G.: A time-dependent model for turbulent transfer in a stratified oceanic boundary layer, Journal of Geophysical Research: Oceans, 92, 6977-6986, https://doi.org/10.1029/JC092iC07p06977, https://agupubs.onlinelibrary.wiley.com/doi/abs/10.1029/ JC092iC07p06977, 1987.

Mellor, G. L., Ezer, T., and Oey, L.-Y.: The Pressure Gradient Conundrum of Sigma Coordinate Ocean Models, Journal of Atmospheric and Oceanic Technology, 11, 1126-1134, https://doi.org/10.1175/1520-0426(1994)011<1126:TPGCOS>2.0.CO;2, https://journals.ametsoc. org/doi/10.1175/1520-0426\%281994\%29011\%3C1126\%3ATPGCOS\%3E2.0.CO\%3B2, 1994.

515 Mellor, G. L., Oey, L.-Y., and Ezer, T.: Sigma Coordinate Pressure Gradient Errors and the Seamount Problem, Journal of Atmospheric and Oceanic Technology, 15, 1122-1131, https://doi.org/10.1175/1520-0426(1998)015<1122:SCPGEA>2.0.CO;2, http://journals.ametsoc. org/doi/abs/10.1175/1520-0426\%281998\%29015\%3C1122\%3ASCPGEA\%3E2.0.CO\%3B2, 1998.

Menemenlis, D., Campin, J., Heimbach, P., Hill, C., Lee, T., Nguyen, A., Schodlok, M., and Zhang, H.: ECCO2: High Resolution Global Ocean and Sea Ice Data Synthesis, AGU Fall Meeting Abstracts, http://adsabs.harvard.edu/abs/2008AGUFMOS31C1292M, 2008.

Monselesan, D. P., O’Kane, T. J., Risbey, J. S., and Church, J.: Internal climate memory in observations and models, Geophysical Research Letters, 42, 1232-1242, https://doi.org/10.1002/2014GL062765, https://agupubs.onlinelibrary.wiley.com/doi/abs/10.1002/ 2014GL062765, 2015.

Mouginot, J., Rignot, E., and Scheuchl, B.: MEaSURES Antarctic Boundaries for IPY 2007-2009 from Satellite Radar, Version 1. Shelves, http://dx.doi.org/10.5067/SEVV4MR8P1ZN., 2016.

Mueller, R. D., Padman, L., Dinniman, M. S., Erofeeva, S. Y., Fricker, H. A., and King, M. A.: Impact of tide-topography interactions on basal melting of Larsen C Ice Shelf, Antarctica, Journal of Geophysical Research: Oceans, 117, https://doi.org/10.1029/2011JC007263, https://agupubs.onlinelibrary.wiley.com/doi/abs/10.1029/2011JC007263, 2012.

Mueller, R. D., Hattermann, T., Howard, S. L., and Padman, L.: Tidal influences on a future evolution of the Filchner-Ronne Ice Shelf cavity in the Weddell Sea, Antarctica, The Cryosphere, 12, 453-476, https://doi.org/https://doi.org/10.5194/tc-12-453-2018, https://www. the-cryosphere.net/12/453/2018/, 2018.

Nakayama, Y., Timmermann, R., Rodehacke, C. B., Schröder, M., and Hellmer, H. H.: Modeling the spreading of glacial meltwater from the Amundsen and Bellingshausen Seas, Geophysical Research Letters, 41, 7942-7949, https://doi.org/10.1002/2014GL061600, https: //agupubs.onlinelibrary.wiley.com/doi/abs/10.1002/2014GL061600, 2014a. 
Nakayama, Y., Timmermann, R., Schröder, M., and Hellmer, H. H.: On the difficulty of modeling Circumpolar Deep Water intrusions onto the Amundsen Sea continental shelf, Ocean Modelling, 84, 26-34, https://doi.org/10.1016/j.ocemod.2014.09.007, https://linkinghub.elsevier. com/retrieve/pii/S1463500314001383, 2014b.

Padman, L., Howard, S. L., and Muench, R.: Internal tide generation along the South Scotia Ridge, Deep Sea Research Part II: Topical Studies in Oceanography, 53, 157-171, https://doi.org/10.1016/j.dsr2.2005.07.011, http://www.sciencedirect.com/science/article/pii/ S0967064506000130, 2006.

Padman, L., Howard, S. L., Orsi, A. H., and Muench, R. D.: Tides of the northwestern Ross Sea and their impact on dense outflows of Antarctic Bottom Water, Deep Sea Research Part II: Topical Studies in Oceanography, 56, 818-834, https://doi.org/10.1016/j.dsr2.2008.10.026, http://linkinghub.elsevier.com/retrieve/pii/S0967064508003615, 2009.

Padman, L., Siegfried, M. R., and Fricker, H. A.: Ocean Tide Influences on the Antarctic and Greenland Ice Sheets, Reviews of Geophysics, 56, 142-184, https://doi.org/10.1002/2016RG000546, https://agupubs.onlinelibrary.wiley.com/doi/abs/10.1002/2016RG000546, 2018.

Padman, L., Howard, S., and King, M. A.: Antarctic Tide Gauge Database, https://www.esr.org/data-products/antarctic_tg_database, 2020.

Pritchard, H. D., Ligtenberg, S. R. M., Fricker, H. A., Vaughan, D. G., van den Broeke, M. R., and Padman, L.: Antarctic ice-sheet loss driven by basal melting of ice shelves, Nature, 484, 502-505, https://doi.org/10.1038/nature10968, http://www.nature.com/doifinder/10. 1038/nature10968, 2012.

Purkey, S. G. and Johnson, G. C.: Antarctic Bottom Water Warming and Freshening: Contributions to Sea Level Rise, Ocean Freshwater Budgets, and Global Heat Gain, Journal of Climate, 26, 6105-6122, https://doi.org/10.1175/JCLI-D-12-00834.1, https://journals.ametsoc. org/doi/10.1175/JCLI-D-12-00834.1, 2013.

Reese, R., Gudmundsson, G. H., Levermann, A., and Winkelmann, R.: The far reach of ice-shelf thinning in Antarctica, Nature Climate Change, 8, 53-57, https://doi.org/10.1038/s41558-017-0020-x, http://www.nature.com/articles/s41558-017-0020-x, 2018.

Richter, O.: Whole Antarctic Ocean Model, https://doi.org/10.5281/ZENODO.3738985, 2020a.

Richter, O.: Post- and preprocessing tools for the ROMS Whole Antarctic Ocean Model, https://doi.org/10.5281/ZENODO.3738998, 2020b.

Richter, O., Gwyther, D. E., Galton-Fenzi, B. K., and Naughten, K. A.: The Whole Antarctic Ocean Model (WAOM v1.0): Development and Evaluation, Geoscientific Model Development Discussion, https://doi.org/10.5194/gmd-2020-164, in review, 2020.

Robertson, R.: Tidally induced increases in melting of Amundsen Sea ice shelves, Journal of Geophysical Research: Oceans, 118, 3138-3145, https://doi.org/10.1002/jgrc.20236, https://agupubs.onlinelibrary.wiley.com/doi/abs/10.1002/jgrc.20236, 2013.

Rosier, S. H. R., Green, J. a. M., Scourse, J. D., and Winkelmann, R.: Modeling Antarctic tides in response to ice shelf thinning and retreat, Journal of Geophysical Research: Oceans, 119, 87-97, https://doi.org/10.1002/2013JC009240, https://agupubs.onlinelibrary.wiley.com/ doi/abs/10.1002/2013JC009240, 2014.

Savage, A. C., Arbic, B. K., Alford, M. H., Ansong, J. K., Farrar, J. T., Menemenlis, D., O’Rourke, A. K., Richman, J. G., Shriver, J. F., Voet, G., Wallcraft, A. J., and Zamudio, L.: Spectral decomposition of internal gravity wave sea surface height in global models, Journal of Geophysical Research: Oceans, 122, 7803-7821, https://doi.org/10.1002/2017JC013009, https://agupubs.onlinelibrary.wiley.com/doi/ abs/10.1002/2017JC013009, 2017.

Schnaase, F. and Timmermann, R.: Representation of shallow grounding zones in an ice shelf-ocean model with terrain-following coordinates, Ocean Modelling, 144, 101 487, https://doi.org/10.1016/j.ocemod.2019.101487, http://www.sciencedirect.com/science/article/pii/ S1463500318302956, 2019. 
Shchepetkin, A. F. and McWilliams, J. C.: The regional oceanic modeling system (ROMS): a split-explicit, free-surface, topographyfollowing-coordinate oceanic model, Ocean Modelling, 9, 347-404, https://doi.org/10.1016/j.ocemod.2004.08.002, http://adsabs.harvard. edu/abs/2005OcMod...9..347S, 2005.

Shepherd, A., Wingham, D., and Rignot, E.: Warm ocean is eroding West Antarctic Ice Sheet, Geophysical Research Letters, 31, https://doi.org/10.1029/2004GL021106, https://agupubs.onlinelibrary.wiley.com/doi/abs/10.1029/2004GL021106, 2004.

Silvano, A., Rintoul, S. R., Peña-Molino, B., Hobbs, W. R., Wijk, E. v., Aoki, S., Tamura, T., and Williams, G. D.: Freshening by glacial meltwater enhances melting of ice shelves and reduces formation of Antarctic Bottom Water, Science Advances, 4, eaap9467, https://doi.org/10.1126/sciadv.aap9467, http://advances.sciencemag.org/content/4/4/eaap9467, 2018.

Stewart, A. L., Klocker, A., and Menemenlis, D.: Circum-Antarctic Shoreward Heat Transport Derived From an Eddy- and Tide-Resolving Simulation, Geophysical Research Letters, 45, 834-845, https://doi.org/10.1002/2017GL075677, https://agupubs.onlinelibrary.wiley.com/ doi/abs/10.1002/2017GL075677, 2018.

Stewart, C. L., Christoffersen, P., Nicholls, K. W., Williams, M. J. M., and Dowdeswell, J. A.: Basal melting of Ross Ice Shelf from solar heat absorption in an ice-front polynya, Nature Geoscience, p. 1, https://www.nature.com/articles/s41561-019-0356-0, 2019.

Tamura, T., Ohshima, K. I., Nihashi, S., and Hasumi, H.: Estimation of Surface Heat/Salt Fluxes Associated with Sea Ice Growth/Melt in the Southern Ocean, SOLA, 7, 17-20, https://doi.org/10.2151/sola.2011-005, https://www.jstage.jst.go.jp/article/sola/7/0/7_0_17/_article, 2011.

Timmermann, R., Wang, Q., and Hellmer, H. H.: Ice shelf basal melting in a global finite-element sea ice/ice shelf/ocean model, Annals of Glaciology, 53, https://doi.org/10.3189/2012AoG60A156, http://www.igsoc.org/annals/53/60/t60A156.html, 2012.

Turner, J., Orr, A., Gudmundsson, G. H., Jenkins, A., Bingham, R. G., Hillenbrand, C.-D., and Bracegirdle, T. J.: Atmosphere-ocean-ice interactions in the Amundsen Sea Embayment, West Antarctica, Reviews of Geophysics, 55, 235-276, https://doi.org/10.1002/2016RG000532, https://agupubs.onlinelibrary.wiley.com/doi/abs/10.1002/2016RG000532, 2017.

Williams, G. D., Herraiz-Borreguero, L., Roquet, F., Tamura, T., Ohshima, K. I., Fukamachi, Y., Fraser, A. D., Gao, L., Chen, H., McMahon, C. R., Harcourt, R., and Hindell, M.: The suppression of Antarctic bottom water formation by melting ice shelves in Prydz Bay, Nature Communications, 7, 12 577, https://doi.org/10.1038/ncomms12577, https://www.nature.com/articles/ncomms12577, 2016.

Wilmes, S.-B. and Green, J. a. M.: The evolution of tides and tidal dissipation over the past 21,000 years, Journal of Geophysical Research: Oceans, 119, 4083-4100, https://doi.org/10.1002/2013JC009605, https://agupubs.onlinelibrary.wiley.com/doi/abs/10.1002/ 2013JC009605, 2014. 